\title{
Financialization and the Labor Share of Income
}

\section{Onur Özdemir ${ }^{1}$}

\begin{abstract}
Financialization has been growing importance in macroeconomic perspectives since the finance-dominated capitalist relations have captured many of the specific positions in an aggregate economy. However, the empirical literature has substantially ignored the examination of the link between an increasing scale of financialization and the rising income inequality. In this study, a major hypothesis is based on the fact that the finance-dominated capitalism has a considerable effect on distributional practices through the channels of bargaining power. By applying the Kaleckian approach, the paper investigates the relationship between financialization and the labor share of national income using a panel dataset of 52 countries over the 1992-2012 period. The results suggest that a higher level of stock market development leads to a more unequal distribution of income and, thus, to the decline of wage share in the national income. Other factors such as globalization and technical change can also exacerbate the decline of wages, coupled with a decrease in the bargaining position of labor measured by unemployment rate and labor force participation rate.
\end{abstract}

Keywords: Bargaining Power, Financialization, Globalization, Labor Share, Stock Markets

JEL Classification: E1, E25, J53

Received: 14 December 2018 / Accepted: 4 September 2019 / Sent for Publication: 5 December 2019

\section{Introduction}

What makes the income share of workers much higher or lower relative to the capital share is still one of the key questions in income-based studies. The distribution of income has been investigated within different contexts, including both classical and modern perspectives. As Dünhaupt (2017: 283) rightfully argues that the topic of income distribution has already been important and one of the major issues in numerous studies, though its analytical framework and theoretical structure have differed in many aspects. Although the historical process has so much witnessed that the distributional conflict was one of the major issues for theoretical knowledge, the triumph of neoclassical thought in the socio-economic era in the post-1980 period has significantly changed the distributional debate by eroding the arguments in favor of functional income distribu-

\footnotetext{
${ }^{1}$ Department of International Trade (English), Istanbul Gelisim University, Istanbul, Turkey, onozdemir@gelisim.edu.tr, ORCID ID 0000-0002-3804-0062.
}

(C) 2019 by the authors; licensee Review of Economic Perspectives / Národohospodářský obzor, Masaryk University, Faculty of Economics and Administration, Brno, Czech Republic. This article is an open access article distributed under the terms and conditions of the Creative Commons Attribution 3.0 license, Attribution - Non Commercial - No Derivatives. 
tion. According to the neoclassical thought, the theoretical background of functional analysis on distribution and allocation lost its significance and relevance. Therefore, it is not possible to refer the presence of distributional conflicts or more specifically of classes since each factor earns the amount of income equal to the value of their contribution to the products. However, the world today is not smooth as the neoclassical paradigm argues at macro-level. The broad picture of the neoclassical period shows that the deterioration in income levels has never been so unequal as part of both advanced and developing country groups. This alternatively means that the distributional conflict between capital- and wage-earners is more severe today. For instance, the share accruing to the labor was shrinking in most OECD and non-OECD countries, as can be seen from Figure 1 for the 1992-2012 period. This means that the profit shares were also rising to the detriment of labor shares.

\section{Figure 1. Labor share trends across country groups}

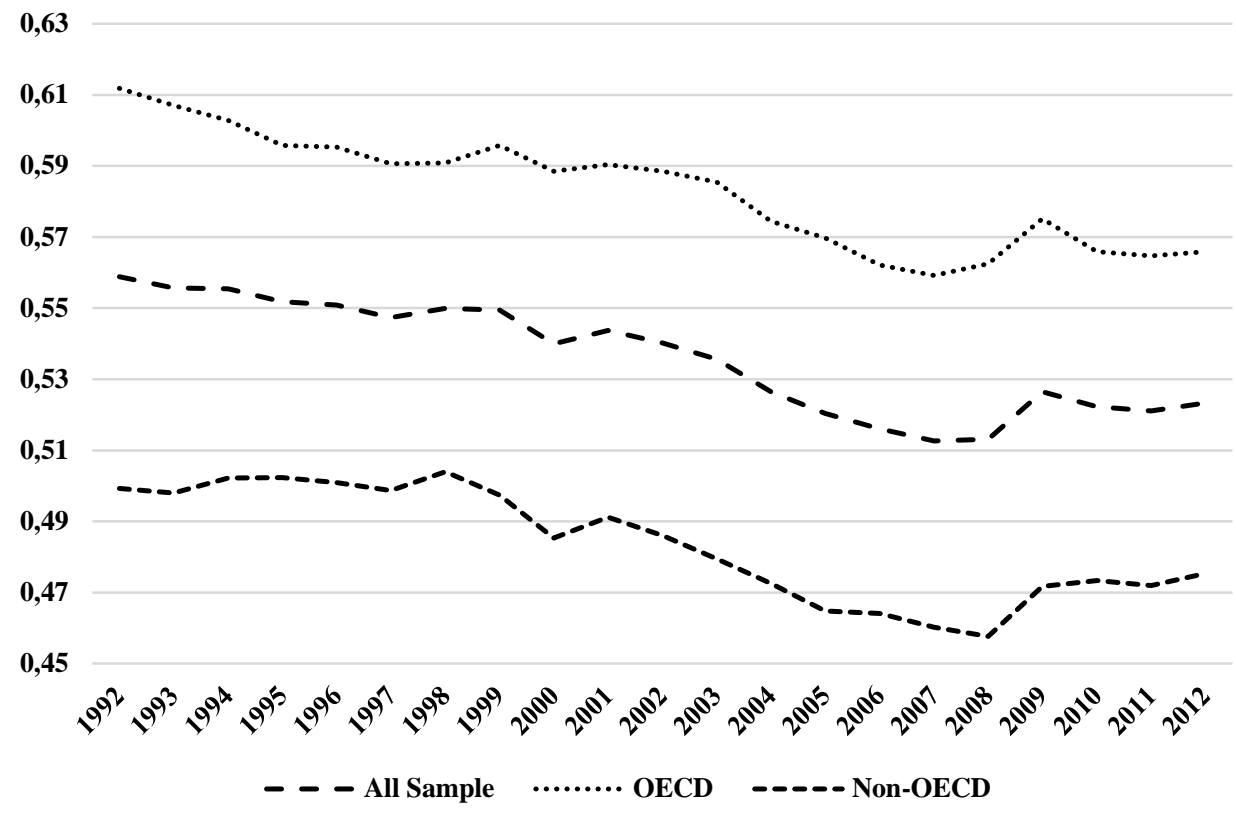

Source: Penn World Tables 9.0 and author's representation

In addition, the distinction between financial and non-financial capital is much complex in this current economic system. One sight of this enigma depends on the development phase of the stock markets concerning their depth and efficiency. In this study, we investigate the effects of financialization in terms of stock markets development on the labor's share. The stock markets are investigated by way of three major indicators: (i) stock market capitalization ratio; (ii) stock value traded in a total economy; and (iii) stock market turnover ratio.

The literature shows that the reasons behind this decline in labor shares are several. For instance, numerous studies have analyzed the effects of technological progress on labor market conditions and have also examined the segregation of labor categories as skilled 
and unskilled over the post-1980 period. Furthermore, the others have lean on the effects of globalization on income distribution pursuant to finance and trade. Finally, the other part of the literature has tried to show the negative impact of the declining bargaining power of labor on income shares over time.

The investigation of the causes of changing income shares of capital and labor has importance for two reasons: (i) to understand the societal differentiations; and (ii) to analyze the macroeconomic consequences. Although each school of thought does not attach equal importance to the distributional issues, still some of them (e.g., Marxian and post-Keynesian thoughts) maintain to argue that the growing inequality should have the highest priority in analyzing the economic booms and busts. The post-Keynesian theories of growth and distribution can essentially be examined under the Kaleckian models. ${ }^{2}$

While financialization is not a new concept in the literature ${ }^{3}$, it became famous after the millennium through the increasing scale of financial markets and institutions in aggregate economic relations. Palley (2007: 3) states that it transforms the functions of the economic system at both micro and macro levels. However, the literature on financialization has not been produced a common definition yet but includes some basic common points (Sawyer, 2013). One of the famous definitions can be found in Epstein (2005: 3): "Financialization means the increasing role of financial motives, financial markets, financial actors and financial institutions in the operation of the domestic and international economies". Alternatively, from the point of Marxian perspective, it can be defined as follows (Lapavitsas, 2013: 802): "Financialization represents a transformation of mature capitalism resting on the altered conduct of non-financial enterprises, banks, and households."

All in all, this paper extends the existing literature on the relationship between financialization and the income distribution by introducing the role of stock markets in the context of financial depth and efficiency, based on the Kaleckian approach to the analysis of income shares, using a panel of 52 developed and developing countries over the period 1992-2012. The main reason why I use this time interval mostly depends on two things: (i) the integration of the Eastern bloc countries into the current sample, and (ii) the data deficiency. The second reason has technical importance since the panel data analysis would become unbalanced if the previous periods are included in the analysis, which results in the reduction of degrees of freedom and thereby unreliable standard errors.

The main objective of this paper is to reveal that unlike the traditional wisdom on positive effects of financial sector development in terms of stock markets on income distri-

\footnotetext{
${ }^{2}$ The following section is devoted to reveal the role of Kaleckian approach in understanding the distributional factors between labor and capital.

${ }^{3}$ To get a comprehensive outlook for financialization please see Baran (1957); Boyer (2000); Crotty (2005); Dumenil ve Lévy (2004, 2011); Fine (2010); Foster (2006, 2010); Foster and McChesney (2009); Glyn (2006); Hilferding ([1981] 2006); Kindleberger and Aliber (2005); Krippner (2011); Lapavitsas (2010); Martin (2002); Polanyi (2001); Stockhammer (2004, 2009, 2010).
} 
bution, there may be other channels in which the distribution of total income is negatively affected through the changing bargaining positions of capital and labor. This is actually the focal point of this study, where the differing in bargaining effects can have negative outcomes in an aggregate economy. In brief, the theoretical context shows that the increasing monopoly power changes the distribution of income in favor of capital; and therefore, the income inequality gap widens across countries. This fact may also valid for within-country income distribution. The critical factor in changing dynamics of income distribution is differing bargaining positions thus the threat option of capital. The factors such as increasing unemployment rate, increasing total population or deunionization are some of them in the process of increasing gap of income distribution. To understand the whole structure of these relations, we will benefit from the theoretical context of Kaleckian approach in the following section.

What drives the unequal distribution of income between capital and labor and makes income inequality increase in recent years across sample countries? This paper attempts to answer this question investigating the relationship between financialization and the labor share of income by way of concentrating on the role of changing bargaining power between capital and labor. While the bulk of studies focus on household-based analysis on this nexus there are also other studies focusing on the importance of class ingredients in which they are examined through the way of looking at differing bargaining positions over time. Therefore, this study also focuses on class-based analysis on the basis of the relationship between financialization and the labor share of income. The main aim of looking at class-based analysis is to reveal changing dynamics of class relations within and between countries in the presence of differing financial relations and motives.

Figure 2 shows the possible reasons for an unequal distribution of income over time, which of those will be empirically investigated in the modeling part. While the effects of financialization and the globalization channels (i.e., trade openness and financial openness) on changing income distribution will be discussed in the following part in detail, the way of technological progress and labor market deregulation can have different channels that affect the labor share accruing in national income. For instance, related to the technological side of this effect, if the production system is based on capital-biased technological development, it may decrease the employment level by reducing the demand for labor, thus creating negative pressure on wages. A similar case can be argued for the labor market deregulation in which less regulation in labor markets can be meant lower bargaining power of labor vis-à-vis capital. Therefore, more implementation of deregulation can create negative effect on the labor share of income by way of increasing the threat option of capital across countries. Additionally, the reduction of government expenditures and the potential economic crises may negatively affect the share of total income between labor and capital. First, the changes in the government structure by reducing the total expenditure using for the economy as a whole can also decrease the total employment leading through the public policies and can reduce the level of income transfers to the labor. Second, the economic crises are also assumed to harm the labor share of income due to several reasons such as differing 
macroeconomic policies, reduction of total production, inefficient income sources, and outflowing of capital to the abroad. ${ }^{4}$

\section{Figure 2. Potential reasons affecting the income distribution}

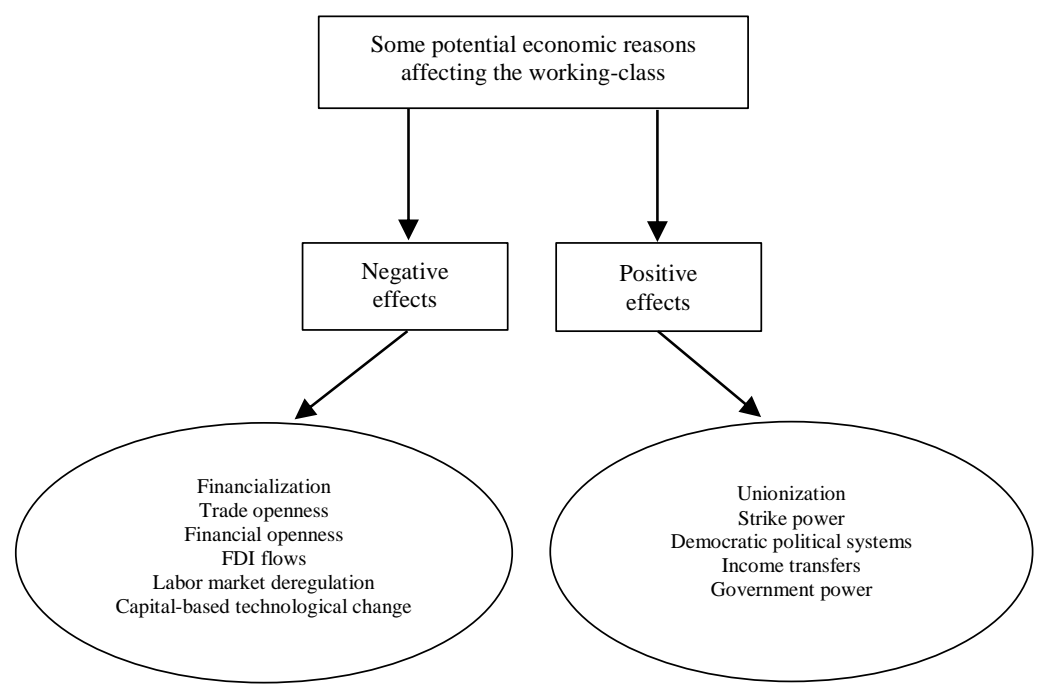

This paper is structured as follows. The second part explains the theoretical specifications between financialization and the labor share of national income, which are based on the Kaleckian model of growth and distribution, acquiring from the work of Hein (2012), and categorizes the major reasons why the income is unequally distributed for workers. The third part focuses on the empirical considerations on the effects of financialization and globalization on the labor share of income. The fourth part explains the dataset. The fifth part focuses on the estimation issues, and part six introduces the empirical results. The last part concludes.

\section{Theoretical Approach}

The Kaleckian distribution model provides a significant theoretical background for discussing the long-run effects of financialization on functional income distribution, especially by way of introducing the bargaining power measures. The model primarily argues that the mark-up pricing of firms in incompletely competitive markets such as monopoly and/or oligopoly is the major approach in the determination of functional income distribution in the industrial sector. In the case of imperfect competition, firms mark up marginal costs, which represent the constant average variable costs ${ }^{5}$, based on their mark-up power; i.e., the degree of monopoly. Unit variable costs include unit di-

\footnotetext{
${ }^{4}$ Further reasons and circumstances are discussed in the literature review and empirical results.

${ }^{5}$ These costs are almost constant until full capacity output given by the available capital stock.
} 
rect labor costs and unit material costs. In addition, since the raw material and semifinished products are assumed to be imported from abroad, it is much proper to include international trade indicator into the model.

Further, the overhead costs are integrated into the mark-up which cover depreciation of fixed capital and gross profits where gross and retained unit profits vary pro-cyclically, given the active price setting of firms. This means that both gross and retained unit profits fall with fixed overhead costs (including also interest and dividend payments and labor salaries) emanating into the increasing output level, or vice versa.

To get the pricing equation in Kaleckian model, I use fixed capital, labor and imported raw materials, and semi-finished goods as inputs for imperfect domestic industrial or service sectors. In this regard, the functional income distribution is affected by two factors: (i) the average mark-up, and (ii) the ratio of unit material costs to labor unit costs.

The pricing equation for a vertically integrated domestic industrial or service sector $j$ is represented in Hein $(2012,2015)$ as follows:

$$
p_{j}=(1+m)_{j}\left(w a_{j}+p_{j} e \mu_{j}\right), m>0
$$

In consideration of the role of stock market development, I extend this pricing equation by including the measure of returns from stocks and bonds as measured by interest rates issued in the financial system, which is formulated as follows:

$$
p_{j}=(1+m)_{j}\left(w a_{j}+p_{j} e \mu_{j}\right)(1+b i)
$$

where $p_{j}$ denotes the output price in sector $j$ and $m_{j}$ is the mark-up, $w$ the nominal wage rate, $a_{j}$ the labor-output ratio, $p_{f}$ the unit price of imported material or semi-finished products in foreign currency, $e$ the exchange rate, $\mu_{j}$ the imported materials or semifinished inputs per unit of output, $i$ returns from stock markets, and $b$ sensitivity to the interest rates.

Since the relation between unit material costs and unit labor costs is given by:

$$
z_{j}=\frac{\left(p_{j} e \mu_{j}\right)}{\left(w a_{j}\right)}
$$

the price equation can also be written as:

$$
p_{j}=\left(1+m_{j}\right)\left[w a_{j}\left(1+z_{j}\right)\right](1+b i)
$$

The gross profit share $\left(h_{j}\right)$ in gross value added of sector $j$ is given by:

$$
h_{j}=\frac{\Pi_{j}}{(\Pi+W)_{j}}=\frac{1}{\frac{1}{\left(1+z_{j}+b i\right) m_{j}}+1}=\frac{\left(1+z_{j}+b i\right) m_{j}}{\left(1+z_{j}+b i\right) m_{j}+1}
$$


with $\Pi$ denoting gross profits (including overhead costs) and $W$ representing wages for direct labor. Put it differently, the wage share for direct labor in gross value added $\left(1-h_{j}\right)$ is:

$$
(1-h)_{j}=\frac{W_{j}}{(\Pi+W)_{j}}=\frac{1}{\left(1+z_{j}+b i\right) m_{j}+1}
$$

Taking the weighted average of sectoral profit shares, the wage share of direct labor $(w=1-h)$ for the economy by the weighted average of the sectoral wage shares is demonstrated as follows:

$$
w=(1-h)=\frac{W}{(\Pi+W)}=\frac{1}{(1+z+b i) m+1}
$$

Therefore, functional income distribution, representing between wage share and profit share, is determined by the following four factors: (i) the mark-up pricing of firms; (ii) the relationship of unit material costs to unit labor costs; (iii) the sectoral composition of the economy; and (iv) the returns from the stock markets.

In case of constant technical conditions of production, where $a$ and $\mu$ are fixed, an increasing gross profit share can either be occurred due to following reasons: (i) rising mark-ups (i.e., the degree of monopoly); (ii) a falling nominal wage rate; (iii) raising prices of imported materials or semi-finished goods in foreign currency; (iv) a rising exchange rate; and (v) profit-led change in sectoral composition of the economy.

According to Kalecki ([1954] 2003: 17-18), there are several causes of changes in the mark-up, or what he calls the degree of monopoly. First, the mark-up is determined by "the process of concentration in industry leading to the formation of giant corporations" (Kalecki, [1954] 2003: 17). If any firm has the power to affect the functioning of the market by influencing the average prices where the price formation depends on this average and thus represents a substantial share of output within an industry, price competition would be limited and then would lead to a substantial increase in the degree of monopoly. This also causes the emergence of tacit agreements and a formal cartel agreement. Therefore, there is a positive relationship between industrial concentration and mark-up.

Second, the mark-up depends on "...the development of sales promotion through advertising, selling agents, etc." (Kalecki, [1954] 2003: 17). This is what we call the nonprice competition relative to the price competition which causes a rise in the degree of monopoly if the former transcends the other in the market system.

Third, Kalecki also considers the effects of overheads to prime costs upon the mark-up. A rise in the level of overheads to prime costs possibly results in the reduction of gross profits. To circumvent the profit loss, the possibility of tacit agreements to emerge 
among firms becomes obvious. Therefore, it leads to an increase in prices to prime costs. $^{6}$

Finally, the mark-up is considered to be high to the significance of the power of trade unions. Essentially, the strength of trade unions might tend to reduce profit shares and thereby the degree of monopoly. Kalecki ([1954] 2003: 18) argues that firms only maintain their price power upon the industry, in case of the existence of powerful trade unions, by increasing their prices following the demands for wage increases, which harm their competitive positions in the industry. Hence, the degree of monopoly is negatively correlated with the bargaining power of labor.

Related to these four determinants proposed by Kalecki ([1954] 2003), Hein (2015) further stresses on some major stylized facts of the financialization as a whole that might be influential on the changes of income shares of workers. These can be listed as follows: (i) increasing shareholder value orientation and short-termism of management; (ii) rising dividend payments; (iii) increasing interest rates or interest payments; (iv) increasing top management salaries; (v) increasing relevance of financial to nonfinancial sector; (vi) mergers and acquisitions; and (vii) liberalization and globalization of international finance and trade. In addition to these characteristics of financialization, Hein (2015) also notes on the characteristics of neoliberalism by focusing on two factors as the deregulation of the labor markets and the downsizing of government, which are all crucial for an understanding of the functional income distribution. ${ }^{7}$

Based on the Kaleckian model of distribution, these characteristics can be investigated under two categories in detail. First, I will deal more with the mentioned-above stylized facts in terms of the relationship between financialization and the labor share of national income, especially by considering the stock market development in the following subsection. Second, the globalization thesis will be presented within the context of finance and trade and their effects on income distribution. All in all, following the literature review, three hypotheses on the income distribution and financialization emerge, which we empirically analyze in the subsequent sections.

Hypothesis 1: There is short- and medium-run negative relationship between financialization and income distribution.

Hypothesis 2: There is a negative link between higher level of globalization and more equal distribution of income in the short-and the medium-run.

Hypothesis 3: There is a U-curve relationship between economic development and unequal income distribution in the short- and the medium-run.

\footnotetext{
${ }^{6}$ For more information about the effects of overhead costs, including the interest and dividend payments, in an empirical framework, please see Lavoie, 1993, 2014; Hein, 2006, 2007, 2008, 2010a, 2010b; Hein and van Treeck, 2010a, 2010b.

${ }^{7}$ In the empirical part, some of these factors (e.g., liberalization and globalization of international finance and trade, labor market deregulation, and downsizing of government) will be analyzed in connection with the financialization process of total economic structure.
} 
The causal link between the variables in the Kaleckian approach is directly based on the relationship between the degree of monopoly and the bargaining power. In that sense, the model discusses the effects of an increasing degree of monopoly on income distribution in an indirect way. In other words, given the effects of mark-up pricing over wages, the model has investigated the role of changing bargaining power and its correlation with the other indicators. Therefore, the Kaleckian approach is discussed through the potential factors that affect the bargaining power and thereby the income distribution between capital and labor. Since each variable implementing in the model is closely related to the degree of monopoly, the outputs of the model accurately reflect the inner dynamics of the Kaleckian approach. Additionally, each potential determinants are wellintegrated into the model by way of their relationship with the bargaining power.

Though the Kaleckian approach basically focuses on the degree of monopoly in relation to the income distribution, the other focal point of this model is that it shows the role of changing bargaining power of labor on distributional practices. In this paper, the stated hypotheses are grounded on this point by way of looking at the bargaining positions of labor against capital; and therefore, the literature review mostly represents the effects of differing bargaining power of labor on the distribution of income over time and across countries. ${ }^{8}$ For instance, the negative correlations of financialization and globalization indicators with income distribution, which are respectively stated in Hypotheses 1 and 2, are integrated into the applied methods through the bargaining channels based on the tools provided by the Kaleckian approach. The main variables, proxied for both financialization and globalization, are linked to the case of bargaining power and its relations with labor share of income. Additionally, Hypothesis 3 is also important in the general framework of this paper thus is empirically tested in the model since the increasing degree of monopoly indirectly captures the economic development process of the capitalist system as a whole. In other words, in any country where the degree of monopoly power (i.e. the mark-up power) is higher has to a large extent developed capitalist relations and thereby a developed economic structure. In that sense, the empirical part also considers the relationship between economic development and income distribution in the presence of Kuznets (1955) hypothesis and the control of other variables. The following section focuses on the empirical considerations based on these stated hypotheses and thereby links them to the labor share of income.

\footnotetext{
${ }^{8}$ The potential reasons and the empirical background of these links will be discussed in the following sections and in the empirical part on the basis of the results of the estimated model. In particular, in relation to the estimation results, the sign of these links will be discussed in detail. Therefore, the later sections are firstly devoted to the empirical considerations related to the circumstances in which they have similar outcomes that we reach in the empirical analysis, and are devoted to range some critical reasons in control of variables using in the model and thus to determine their role in financialization-income distribution nexus in the presence of changing bargaining positions of capital and labor.
} 


\section{The Empirical Considerations for the Effects of Financialization and Globaliza- tion on Labor Share of Income}

\subsection{Financialization and the Labor Share of Income}

The impact of an increasing scale of financialized relations, in case of a higher rate of stock market development, was started to become a stylized fact in the late 1980s and exacerbated in the mid-1990s. The term 'shareholder value' thus became one of the most popular research topics in changing priorities and behaviors of non-financial firms and of financial corporations as well. For instance, Lazonick and O'Sullivan (2000) note that the behaviors of firms in the post-1980s have changed towards more oriented to the maximization of shareholder value and have entrenched as a principle of corporate governance. This intention of non-financial firms was the breaking point in the transformation of the traditional motives for financial investments and the employment structure. The priority of corporations became the interest of shareholders and their attitudes through financial investments. In this regard, the corporations to a large extent have pushed their real investments and thereby their job strategies into the background for short-term financial interests of shareholders. As Lazonick and O'Sullivan (2000: 24) rightfully identify that the orientation of top managers has shifted from "retain and reinvest" to "downsize and distribute". By the 1980s, the integration of top managers into the organization was dissolved through two conditions, such that the separation of share ownership and the collapse of managerial control.

Further, the top managers were encouraged to standardize their own interests with financial interests instead of the interests of productive organizations due to following variable remuneration schemes which were both indexed to the short-term aims of the management: (i) the deregulated financial system, and (ii) the rise of institutional investors as a holder of corporate stocks. This change in firm's management strategy, which was exacerbated the volume of dividend payments and stock purchases, resulted in an increasing debt burden of the non-financial sector and payments for interests and dividends (Dünhaupt, 2013: 8). ${ }^{9}$ Hence, the increasing trend for maximization of shareholder value, coupled with a rise in interest and dividend revenues of corporations and movements in stock prices, have to be found their reflections in changing income distribution over the post-1980 period with a growing demand for financial resources and a market power of finance, which leads to a strong gains in stock markets for specific income groups, especially for which of investors who expose their savings to a higher risk of financial assets. In that sense, financialization might exert its effect on labor's share of income through stock market liquidity and participation, which might result in a rise of stock price volatility, increasing importance of short-term but risky financial investments, asymmetric impact of financial and credit market imperfections, increasing number of financial investors involved in risk-taking, concentration of total assets among the wealthy, and downsizing of the corporate control.

\footnotetext{
${ }^{9}$ For more information and the critiques about the term of "shareholder value" please see Williams (2000).
} 
Although numerous studies focus on the stock market development over the post-1980 period, the empirical investigations that measure the effects of financialization, especially those analyzing in case of stock market development, on the labor share of income, are limited in the literature. According to the traditional perspectives, a more liquid stock market provides opportunities for investors in case of any financial frictions to exit the market thus stimulate long-term investments and more productive projects as well. So, the return of investments would be much higher with higher productivity of capital, which would encourage more savings and physical capital investments, leading to capital accumulation and thus higher employment level with higher wage level. In fact, the financialization thesis in terms of stock markets evolution finds out many different outcomes in contrast to the mainstream framework about its relations with the functional income distribution. Favilukis (2013) notes that labor income inequality has been on the rise while returns on equity have been high, which opens debate for the disproportion of the distribution of gains to the wealthy and the concentration of total assets. Das and Mohapatra (2003) examine the effects of stock market development for specific income groups subject to the equity-market liberalization and find that the gains from stock market liberalization are much higher for upper quintile income groups at the expense of middle quintile income groups. They also add that the liberalization of domestic markets does not have a significant impact on the lowest income quintiles. Sawhey and DiPetro (2006) note for 73 countries for the year 2000 that there is a positive link between stock market wealth and income inequality. In particular, it is obvious from the empirical results that higher the stock market capitalization means higher the income shares of upper quintile but lowers the bottom quintile. Dumenil and Lévy (2004: 82) argue that financialization affects the income shares by way of changing economic structure within the context of three factors: (i) increasing scale of financial enterprises, (ii) increasing integration of non-financial enterprises into the financial operations, and (iii) rising ownership for stock shares and other securities by households. They also add that maximization of shareholder value has to be included in the mentioned-above factors as an administrative criterion, which has an ample effect on profit shares. Blau (2018) focuses on the effects of stock market liquidity on the level of income equality and finds that liquidity-induced growth disproportionately but positively affects the poor in comparison to the rich. However, this is controversial with the empirical results of Stockhammer (2009) and ILO (2011) since their financialization indicators, which comprise of all forms of foreign assets and liabilities as a share of GDP, are negatively related to the wage share. Dünhaupt (2017) also finds a negative relationship between the labor share of national income and financialization (measured by interest payments and dividend payments relative to GDP) for 13 OECD countries for the 19862007 period. Favilukis (2013) builds a model to analyze the joint movements in income shares, stock market participation, and equity premium. The evidence shows that there was a large increase in labor income inequality and wealth inequality, a rise in the proportion of stockholders, loosening of credit standards, and a fall in the expected equity premium with a prolonged stock market boom.

The second pillar of the relationship between financialization and labor share of income might be deduced from the weak bargaining position of labor relative to capital. Although the details would be further discussed in the following sub-section in the case of trade openness and financial globalization, it is worth mentioning to remind that it is not limited only within the financial era. While changing economic visions of corporations 
towards more financial investments primarily transformed the employment structure and the sectoral composition by increasing demand for more skilled workers and promoting automatization in a production system, these factors also intensified with the concentration of capital through a rising scale of mergers and acquisitions in order to consolidate their market power and competitive strengths both domestically and globally, over the course of the 1980s and so on. Hence, the "downsize and distribute" strategy of corporate governance of the post-1980 period accompanied the intensity of capital and declining bargaining power of labor, which results in lying out of workers, especially the unskilled workers. Depending on Post-Keynesian theory, all of these factors might have a significant impact on the decreasing bargaining power of labor via three channels: (i) increasing unemployment rate (e.g., due to rising tendency towards more finance-based investments of non-financial firms and thus pursuing for financial motives), (ii) increasing number of unemployed people in total labor force participation ratio, and (iii) the deregulation of labor markets.

\subsection{Globalization and the labor share of income}

Globalization is not only a fact or a concept but more than this. It gathers different sources of things from diverse disciplines. Rightfully, Norris (2000: 155; quoted in Dreher, 2006: 1092) intends to understand the globalization as “...a process that erodes national boundaries, integrates national economies, cultures, technologies, and governance, and produces complex relations of mutual interdependence". Therefore, the multifunctional structure of globalization thesis has a potential effect on the allocation of resources and thereby the functional income distribution. In this regard, the globalization thesis might exert its impact on labor's share of national income through two channels: (i) trade openness; and (ii) financial openness. Throughout the 1980s, global competitiveness has stimulated an increase in global value chains led by multinational and transnational firms pursuant to the neoliberal strategies of capital accumulation. According to Milberg and Winkler (2013), these have boosted international trade and foreign direct investment, including both inflows and outflows, have changed the role of foreign demand within the economic development process and, thus, the effects of trade on income distribution. They show that the labor share of national income is negatively affected by increasing scale of offshoring and the collapse of the institutional structure and conclude that labor market institutions have direct importance in mediating the effects of globalization on workers. Therefore, the liberalization of trade might only have a positive impact on the interests of export-oriented technology-led firms, which increases the income of skilled workers, but the same effect on the wage shares of unskilled workers are ambiguous. Anderson (2005), for example, ranges five different channels through which a higher trade openness could lead to a change in income distribution: (i) relative factor returns; (ii) allocational/distributional composition of real incomes among groups in society; (iii) regional distribution of capital; (iv) the labor force composition in gender framework; and (v) the use of redistribution policies.

Although the mainstream arguments evaluate the effects of trade openness on growing income disparities, subject to the main building-block of international trade theory, the classical dichotomy of these arguments are critically assessed by including multiple skill-related categories of workers (Wood, 1994) in North-South distinction, countrygroups analysis (Davis, 1996), and categorization of traded goods (Feenstra and Hanson, 
1996). In addition, technology-led trade flows have increased the wage dispersion among workers by way of increasing demand for skilled labor (Lee and Vivarelli, 2004). In particular, Zhu and Trefler (2005) focus on technological catch-up in case of increasing trade flows to range the causes of production shift of the least skill-intensive Northern products to the Southern countries in response to the model of Feenstra and Hanson $(1996,1997)$ which is based on a continuum of goods with differing proportions of skill intensity, and find that technological transfers lead to a higher demand for skilled labor in both developed and developing country groups (i.e., increasing wage dispersion among different skills of workers). According to Meschi and Vivarelli (2009: 288), if the technological differences are assumed to be a widely accepted factor using in studies which are investigated the effects of trade openness on income distribution, a higher ratio of trade liberalization stimulates technology diffusion from North to South and thus both labor demand and relative wages are largely determined by skill intensity of the transferred technology. Therefore, the income distribution becomes dependent on the changes in the skill composition of workers and skill-biased nature of technological progress (see, for instance, Berman et al., 1994; Autor et al., 1998; Piva and Vivarelli, 2004; Acemoglu and Autor, 2011).

In addition, technology upgrading in response to international openness might exert a significant impact on wage dispersion by leading to develop new technologies, subject to new ideas and innovations, which are more biased towards skilled labor (Wood, 1997). Thoenig and Verdier (2003) argue that if such is that case it might occur since the firms would be increasingly exposed to the external competition which of those are tended towards to bias their technological upgrading more skilled labor and thus alter their workforce towards using skilled workers. In the case of developed and developing countries distinction, the former one might seem to gain more from technology-led trade transactions with a higher demand through skilled workers and thus widens the wage dispersion. However, Goldberg and Pavcnik (2007: 34) extend this case by arguing that this might also valid for middle-income countries if they subject to import competition against low-income developing countries within low skill-intensive sectors. On the other hand, this directs firms to employ skilled workers in copy-paste production such as reverse engineering or non-creative investments (e.g., FDI), which might lead to a widening of wage dispersion between skilled and unskilled workers in developing countries. In particular, this case is concentrated with increasing international flows of capital goods and thereby embodied technology, which converges the skill-biased technology levels between North and South, and alters intra-class wage distribution in favor of skilled workers (Acemoglu, 2003; Robbins, 2003; Schiff and Wang, 2004).

On the other hand, there are also country-based and firm-based studies which of those examine the arguments whether there is a positive effect of firms' export activities and opening export markets on productivity level and efficiency gains pursuant to exportby-learning hypothesis (Crespi et al., 2008; Ito, 2012; De Loecker, 2013). In this regard, as Goldberg and Pavcnik (2004) note that the form of exports should be evaluated in case of quality whether it reflects "firm productivity" or "product quality". This distinction has ample importance for analyzing income distribution since it might have a direct relationship between quality upgrading and demand for high-skilled workers (Verhoogen, 2008). Therefore, sources of an increasing scale of skill premium might also alter income shares of labor and capital as well as intra-class wage levels. 


\section{Data}

The dataset of this paper includes several indicators covering both economic and social factors as well as political factors. The dependent variable is the labor share of national income. I follow the previous studies and measure labor's share as the compensation of employees over GDP. The residual part is depicted as the capital share. ${ }^{10}$ Although there are different types of measurement techniques in the empirical literature ${ }^{11}$, the major drawback of this traditional method depends on the fact that the unadjusted use of employees' compensation may bias over time by excluding the self-employment issue (Krueger, 1999; Gollin, 2002). In addition, the data are largely collected from the formal sector thus informal side is ignored, which reports labor share either more or less (Jayadev, 2007: 426). To account for this bias, the earnings of self-employed are measured in data thus the dependent variable is regarded as an adjusted version of the labor share of income taken from Penn World Tables (PWT) 9.0. While the numerator of labor's compensation includes both dependent and self-employed workers, the denominator of GDP excludes net indirect taxes. ${ }^{12}$

In virtue of financialization, the estimation model uses three kinds of variables, which are obtained from the Global Financial Development Database updated in June 2017: (i) stock market capitalization to GDP; (ii) stock market total value traded to GDP; and (iii) stock market turnover ratio. Additionally, I use the interaction of financialization measures and financial openness index to examine whether financial liberalization conditions the effect of financialization on labor's share. The main idea behind the interaction terms suggests that promoting more open financial accounts without providing developed stock markets might harm labor's share. ${ }^{13}$ The financial openness index is taken from Aizenman (2018), which is a de-jure measure of financial liberalization in which the data has two distinctive features: (i) covering a large time period of 19702015 for 182 countries; and (ii) comparable with other measures of cross-border financial flows.

For the measurement of globalization, three different variables are applied. First, the adjusted (real) trade openness index, taken from World Development Indicators (WDI), is used to measure the effects of international trade on labor's share. It is measured as exports plus imports divided by GDP and then is also adjusted by the price of GDP (i.e., GDP in exchange rate US\$ divided by GDP in PPP US\$). The price of GDP is obtained from Penn World Tables 9.0. One of the major reasons why I use this indicator depends

\footnotetext{
${ }^{10}$ Hence, there are one-to-one relations for increases (decreases) in capital's share by a certain amount immediately reflecting as decreases (increases) in labor's share by the same amount.

${ }^{11}$ Guerriero (2012) provides a far-reaching investigation on the methods of the measurement of labor share.

${ }^{12}$ Feenstra et al. (2015: 3172): "Where mixed income is not available as a separate data item in a country's national accounts, we impute the labor income of the self-employed either by assuming that self-employed earn the same average income as employees or based on the share of agriculture in value added".

${ }^{13}$ For the studies that focus on the joint effect of capital account openness and finance-based measures please see Bumann and Lensink (2016), Eichengreen et al. (2011), Chinn and Ito (2002), Reinhardt et al. (2013), Haan et al. (2018).
} 
on the extent of the tradable and non-tradable sectors. Suppose that trade is positively linked to productivity, but tradable sectors are much favored in terms of productivity gains compared to non-tradable sector. In such a case the relative price of non-tradable goods increases, and thus trade-to-(nominal) GDP ratio decreases subject to the condition that demand is relatively inelastic for non-tradable goods. Therefore, trade-led productivity gains follow a negative link with trade-to-(nominal) GDP decreases. To avoid this problem, Alcala and Ciccone (2004) produce a new method for measuring trade openness in which the nominal term of trade openness is adjusted by the deflator and so international price differences for non-tradable goods and services are corrected for the denominator.

As second and third variables for globalization, FDI inflows and outflows as a share of GDP are applied which are both obtained from United Nations Conference on Trade and Development (UNCTAD) database. There are multiple ways that FDI can affect labor's share either reducing employment opportunities of decreasing bargaining power of workers. Based on these factors, Anderson and Nielsen (2002) specify two main reasons which lead to the emergence of above-listed factors: (i) a rise of deindustrialization in advanced countries; and (ii) a rise of multinational firms. As an important channel of internationalization, the link between FDI (including both inflows and outflows) and income inequality has been investigated by numerous studies (Tsai, 1995; Basu and Guariglia, 2007) and has been extended in the context of increasing wage dispersion between skilled and unskilled workers and of labor market segmentation (Gopinath and Chen, 2003; Choi, 2006). More specifically, Kristal (2010) examines the effects of FDI inflows on labor's share and finds that there is a negative correlation between each other. Further, the globalization and the labor share of national income can be jointly affected by the conditions of financial liberalization proxied by the financial openness index of Aizenman (2018).

Besides the globalization indicators, the bargaining power of workers is measured by two indicators. The first is the unemployment rate, which is obtained from IMF World Economic Outlook, and ILO KILM database. As a second variable, I use labor force participation rate where the series are obtained from the WDI database. The rationale for using these variables depends on the following context: if the number of unemployed people increases relative to that of the number of employed people in the workforce, it creates a downward pressure on wages since the excess supply of labor leads firms to reduce unit labor costs by employing cheap labor thus possibly results with the erosion of bargaining power of workers in favor of capital.

In addition to these measures, I include several control variables such as general government final consumption expenditure (\% of GDP), exchange rate stability index, welfare-relevant TFP, and crisis dummy. First, general government final consumption expenditure is obtained from WDI database and defines in case of the following factors: all government current expenditures for purchases of goods and services, cost expenditures on national defense and security, and the exclusion of government military expenditures that are part of government capital formation. I expect government expenditure to have a positive coefficient since it has a direct and significant impact on aggregate income in national accounts and thus on employment, which creates an extra income for working people. 
Second, I include measures of exchange rate stability index, conjecturing that the instability hurts the lowest income quintiles relatively more than the upper quintile since the former is much unstable to the changes in prices resulting from the fluctuations in exchange rates and therefore there is no hedge for these people that keep them out of the exposure of exchange rate instability. I thus expect that there is a positive correlation between stable exchange rates and the labor's share. The series is obtained from Aizenman's (2018) trilemma index.

Third, I also use welfare-relevant TFP at constant national prices, which is taken from Penn World Tables 9.0. One of the major reasons why I include this variable into the model essentially depends on the rationale that the series calculate the effects of welfare-relevant productivity gains on labor's share. It is expected that if the productivity gains are higher than the real wage increases, the coefficient would be negative.

Finally, I consider the impact of the global crisis on labor's share. There are two major reasons that I use this variable in the empirical model. The first reason is related to its large effects on output and employment levels and thereby indirectly to the distribution of aggregate income shares. The second reason has theoretical importance to remove the time-fixed effects in the model. However, descriptively, the global crisis is unlikely to be the essential explanatory variable in case of the observed relationships: the negative correlations between financialization and labor's share are also held in non-crisis periods, and the distributional recovery increased in crisis time.

\section{Estimation Issues}

The sample includes 52 OECD and non-OECD countries ${ }^{14}$. To test the following theoretical model, I use panel data, that is, yearly observations for each country, which covers the 21-year period from 1992 to $2012 .{ }^{15}$ In total, the number of observations is 1092 , which is formed by country-year combinations. ${ }^{16}$ As shown in the number of observations, the panel structure is balanced in all specifications, which preserve us from losing large degrees of freedom thus makes the empirical outcomes much consistent relative to the results of an unbalanced panel. Deviating from the previous empirical studies such as Dünhaupt (2017), I use Driscoll and Kraay's (1998) method to examine the linear relationship between financialization and the labor share of national

\footnotetext{
${ }^{14}$ Many of these countries are classified as the advanced economies in terms of their aggregate income. Therefore, the main rationale for the selection process of these countries depends on three factors. First, the sample countries are classified as high and high-middle income countries. Second, they have enhanced capitalist relations, especially in terms of the financial sector. In those countries, the stock markets are well-developed in contrast to the rest of the world. Therefore, the inclusion of less financially developed countries can provide biased results for the relationship between income distribution and financialization. Third, the class dynamics between capital and labor are also well-developed and the institutional structure is well-designed in those countries. See Appendix A3 for a list of selected countries.

${ }^{15}$ The selection of the sample countries depends on two factors: (1) data availability, especially for financialization; and (2) a settled labor markets policies, rules and conditions.

${ }^{16}$ Appendix A2 reports summary statistics for the variables using in the model.
} 
income. As I intend in within-country comparisons for theoretical and methodological considerations, I analyze the potential determinants of labor share of national income in panel data, controlling for the diagnostic issues by way of Driscoll-Kraay method.

When dealing with panel data, the estimation of the model by fixed-effects estimators can provide some major advantages. For instance, there might be omitted variables that vary across units but are constant over time. These estimators exploit the within-country variation as a means of eliminating unit heterogeneity and therefore provide unbiased and consistent estimates of the parameters in cases where unit-effects are randomly correlated with estimated independent variables (Halaby, 2004; Kristal, 2010). Hence, they avoid omitted variable bias, to a large extent, through capturing unobserved effects. By applying fixed-effects estimators, however, the cross-country variations are still not captured while within-country variations to explain labor's share are hold.

To test the hypotheses explained in the theoretical approach, I consider the following econometric model:

$$
\begin{aligned}
& \mathrm{LS}_{\mathrm{it}}=\beta_{0}+\beta_{1} \text { STOCK_CAP }_{\mathrm{it}}+\beta_{2} \text { STOCK_TRADE }_{\mathrm{it}}+\beta_{3} \text { STOCK_TURN }_{\mathrm{it}} \\
& +\beta_{4} \text { FIN_LIB }_{\text {it }}+\beta_{5} \text { OPEN }_{\text {it }}+\beta_{6} \text { INW_FDI }_{\text {it }}+\beta_{7} \text { OUT_FDI }_{\text {it }} \\
& +\beta_{8} \text { GOV_EXP }_{\text {it }}+\beta_{9} \text { REER }_{\text {it }}+\beta_{10} \text { TFP }_{\text {it }}+\beta_{11} \text { UNEMP }_{\text {it }}+\beta_{12} \text { LABFORCE }_{i t}
\end{aligned}
$$

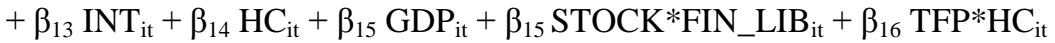

$$
\begin{aligned}
& +\alpha_{\mathrm{i}}+\mathrm{u}_{\mathrm{t}}+\varepsilon_{\mathrm{it}}
\end{aligned}
$$

where $i(\mathrm{i}=1, \ldots, \mathrm{N})$ and $t(\mathrm{t}=1, \ldots, \mathrm{T})$ denote the country and time, respectively. In this equation, LS represents the economy-wide labor share in the country $i$ and time $t$. The parameter of interest is the coefficients $\beta_{1}, \beta_{2}$, and $\beta_{3}$, representing the conditional correlation of the labor share coefficient with the chosen measures of financialization, which are stock market capitalization (STOCK_CAP), stock value traded (STOCK_TRADE) and stock market turnover (STOCK_TURN). In this model, I also include the following control variables to capture their effects on the labor share of national income. Globalization is captured by financial openness (FIN_LIB), real trade openness (OPEN), inward FDI (INW_FDI), and outward FDI (OUT_FDI). Bargaining power of labor is estimated by unemployment rate (UNEMP) and labor force participation rate (LABFORCE). The macroeconomic and structural conditions are captured by general government final consumption expenditure (GOV_EXP), real exchange rate stability (REER), real interest rates (INT), and GDP per capita (GDP). The educational effect of economic development is captured by human capital index (HC) and the productivity is estimated by welfare-relevant total factor productivity (TFP). Finally, I also use some interaction terms to analyze the mutual impact of the indicators on the deviations of income distribution. First, I capture the interaction effect of both financialization and financial liberalization (STOCK_CAP*FIN_LIB; STOCK_TRADE*FIN_LIB; STOCK_TURN*FIN_LIB) on the labor share of income. Second, I interactively control the effect of welfare-relevant total factor productivity and human capital (TFP*HC) on the labor's share. In addition, $\beta_{0}$ denotes the constant, $\alpha_{i}$ country-fixed effects, $u_{t}$ time- 
fixed effects, and $\varepsilon_{\text {it }}$ the error term ${ }^{17}$. Hence, it provides us to avoid any potential spurious correlations to emerge with a rise of financialization.

In the theoretical background of panel data, however, the violation of the standard regression assumption of independent and identically distributed errors is possible to occur and thus should be corrected for the reliability of the model. In other words, the panel data series might be characterized by complex error structures, which mean that the disturbances are very likely to be heteroskedastic and contemporaneously correlated across panels. As Chen et al. (2006: 2) note that employing OLS to data with nonspherical errors leads to obtain an inefficient and biased coefficient estimates for standard errors. Beck and Katz (1995) range three kinds of problems that the errors might have as follows: (i) panel heteroscedasticity; (ii) contemporaneous correlations; and (iii) the serial correlation. In that case, the use of Driscoll-Kraay method provides robust theoretical means to adjust for these diagnostic issues through the fixed-effects method and therefore results with consistent estimates for fixed-effects estimations. When the time period is large enough, this method shows that the standard non-parametric time-series covariance matrix estimators might be developed for all general forms of spatial and periodic correlations as robust and also provides the consistency of the covariance matrix estimators; irrespective to the cross-sectional dimension of $N$ (e.g., even when $\mathrm{N} \rightarrow$ $\infty)$. Hence, Driscoll-Kraay method is produced as an alternative to Panel-Corrected Standard Errors (PCSE) method developed by Beck and Katz (1995), Parks (1967), and Kmenta (1986), which are produced weak robust covariance matrix estimators when T is small.

At first, I run OLS regression in levels with the country- and time-fixed effects and test for groupwise heteroskedasticity using a modified Wald test, which shows that the null hypothesis of constant variance is rejected. Second, the Frees's and Pesaran's tests of cross-dependence are applied to ascertain cross-sectional dependence and the results for each test indicate that residuals across units are correlated. Finally, I examine whether there is a serial correlation by using Baltagi-Wu and Wooldridge tests for autocorrelation. The results show that there is a first-order autocorrelation. Since both of these diagnostic issues make OLS estimators invalid, the Driscoll-Kraay method is applied. This is based on Newey-West type of correction for the average cross-section series and mitigates within-group heteroskedasticity and contemporaneous correlation of errors. The estimations are also adjusted for serial correlation in panel-specific conditions.

Further, panel data analysis needs to be dealt with the tests for unit roots or stationary issues. Panel unit root testing is originated from time series unit root testing and thus it is so much possible that the panel dataset might be non-stationary. I apply two types of unit root tests due to the existence of diagnostic problems. On the one hand, a panel data unit root test of the first generation, which is called as Levin-Lin-Chu (LLC) test (Levin

\footnotetext{
${ }^{17} \alpha_{\mathrm{i}}$ denotes a full set of country-fixed effects which capture country characteristics that are constant over time and the error term $\varepsilon_{i t}$ has zero mean conditional on the regressors. $u_{t}$ also picks up the aggregate sample-wide shocks (such as economic crisis, financial crisis or banking crisis) to labor's share.
} 
et al., 2002) is examined and assumes that all panels have the same autoregressive parameter and should be strongly balanced. On the other hand, I also apply Im-PesaranShin (IPS) test (Im et al., 2003) for two reasons. First, IPS test considers the problem of cross-sectional dependence. Second, unlike the LLC test, IPS test relaxes the assumption of a common autoregressive parameter thus allows each panel to have its own autoregressive parameter. In addition, IPS test does not require strongly balanced data but the distinction between each individual time series should not exist. To avoid such a case, I take the first-differences of the series since some of the variables are integrated of order one. However, in first-difference estimations, fixed effects are dropped where first differences of the observations would control for any unit-fixed effects. Hence, both feasible generalized least squares (FGLS) and PCSE estimates are applied instead of using the Driscoll-Kraay method. All models show that there is strong evidence of serial and cross-sectional correlation and of heteroskedasticity in the panel. ${ }^{18}$

\section{Estimation Results}

The Kaleckian approach is reflected through the bargaining channel between capital and labor in the model. In other words, while the Kaleckian approach has different aspects, the relationship between financialization and the labor share of income is linked to the changing bargaining positions of capital and labor in control of other variables. Therefore, the Kaleckian approach indirectly represented in the model by way of looking at differentiation in the bargaining channel and its role in financialization-income distribution nexus.

Tables 1 and 2 present the first set of baseline estimation results measured in levels and first-differences, respectively. Table 1 summarizes the level estimations in which the Driscoll-Kraay method is used in fixed-effects. Further, Table 2 displays the empirical results in first-differences using both FGLS and PCSE estimates. The estimates in columns (1), (2), and (3) use FGLS; columns (4), (5), and (6) use PCSE. In each specification, the financialization variables are measured separately. The major difference in each specification depends on the measurement of the standard errors. Thus I do not change the model structure in the sense of variables. While both specifications include time-fixed effects, the country-specific effects are only included in Table 1. Since some of the variables exhibit a non-stationary trend, I also apply Im-Pesaran-Shin test (Im et al., 2003), and therefore the specification results in Table 2 are much reliable than Table 1 However, each estimation result is similar even the standard errors are somewhat different.

The globalization indicators are consistent with the hypothesized relationships presented in the previous section and have a significant impact on the labor's share. First, the real trade openness - traditional trade openness (export plus imports as a share of GDP) deflated by the price of GDP - has a negative and significant effect on the labor share of national income.

\footnotetext{
${ }^{18}$ In addition to these tests, the multicollinearity was also tested and founded that the variance inflation factor is not higher than 10 for each variable.
} 
Table 1. Estimation in levels (dependent variable: labor share of income)

\begin{tabular}{|c|c|c|c|c|c|c|}
\hline & (1) & (2) & (3) & (4) & (5) & (6) \\
\hline STOCK_CAP & $\begin{array}{l}-0.000 * * \\
(0.000)\end{array}$ & $\begin{array}{l}-0.000^{* *} \\
(0.000)\end{array}$ & & & & \\
\hline STOCK_CAP*FIN_LIB & $\begin{array}{l}0.000 \\
(0.000)\end{array}$ & $\begin{array}{l}0.000^{*} \\
(0.000)\end{array}$ & & & & \\
\hline STOCK_TRADE & & & $\begin{array}{l}-0.000 \text { *** } \\
(0.000)\end{array}$ & $\begin{array}{l}-0.001 \text { *** } \\
(0.000)\end{array}$ & & \\
\hline STOCK_TRADE*FIN_LIB & & & $\begin{array}{l}0.000 * * * \\
(0.000)\end{array}$ & $\begin{array}{l}0.000 * * * \\
(0.000)\end{array}$ & & \\
\hline STOCK_TURN & & & & & $\begin{array}{l}-0.000 \\
(0.000)\end{array}$ & $\begin{array}{l}-0.000 \\
(0.000)\end{array}$ \\
\hline STOCK_TURN*FIN_LIB & & & & & $\begin{array}{l}-0.000 \\
(0.000)\end{array}$ & $\begin{array}{l}-0.000 \\
(0.000)\end{array}$ \\
\hline FIN_LIB & $\begin{array}{l}-0.004 \\
(0.004)\end{array}$ & $\begin{array}{l}-0.007 \\
(0.004)\end{array}$ & $\begin{array}{l}-0.005 * \\
(0.002)\end{array}$ & $\begin{array}{l}-0.007 * * \\
(0.002)\end{array}$ & $\begin{array}{l}0.003 \\
(0.003)\end{array}$ & $\begin{array}{l}0.002 \\
(0.003)\end{array}$ \\
\hline OPEN & $\begin{array}{l}-0.029 * * * \\
(0.006)\end{array}$ & $\begin{array}{l}-0.021 * * * \\
(0.005)\end{array}$ & $\begin{array}{l}-0.030 * * * \\
(0.006)\end{array}$ & $\begin{array}{l}-0.023 * * * \\
(0.005)\end{array}$ & $\begin{array}{l}-0.029 * * * \\
(0.007)\end{array}$ & $\begin{array}{l}-0.024 * * * \\
(0.005)\end{array}$ \\
\hline INW_FDI & $\begin{array}{l}-0.000 \\
(0.000)\end{array}$ & $\begin{array}{l}-0.000 \\
(0.000)\end{array}$ & $\begin{array}{l}-0.000 \\
(0.000)\end{array}$ & $\begin{array}{l}-0.000 \\
(0.000)\end{array}$ & $\begin{array}{l}-0.000 \\
(0.000)\end{array}$ & $\begin{array}{l}-0.000 \\
(0.000)\end{array}$ \\
\hline OUT_FDI & $\begin{array}{l}0.000 \\
(0.000)\end{array}$ & $\begin{array}{l}0.000 \\
(0.000)\end{array}$ & $\begin{array}{l}0.000 \\
(0.000)\end{array}$ & $\begin{array}{l}0.000 \\
(0.000)\end{array}$ & $\begin{array}{l}0.000 \\
(0.000)\end{array}$ & $\begin{array}{l}0.000 \\
(0.000)\end{array}$ \\
\hline GOV_EXP & $\begin{array}{l}0.003 * * * \\
(0.001)\end{array}$ & $\begin{array}{l}0.003 * * * \\
(0.001)\end{array}$ & $\begin{array}{l}0.003^{* * * *} \\
(0.001)\end{array}$ & $\begin{array}{l}0.004 * * * \\
(0.001)\end{array}$ & $\begin{array}{l}0.003 * * * \\
(0.001)\end{array}$ & $\begin{array}{l}0.004 * * * \\
(0.001)\end{array}$ \\
\hline REER & $\begin{array}{l}0.011 \\
(0.007)\end{array}$ & $\begin{array}{l}0.012 * \\
(0.007)\end{array}$ & $\begin{array}{l}0.008 \\
(0.007)\end{array}$ & $\begin{array}{l}0.009 \\
(0.007)\end{array}$ & $\begin{array}{l}0.010 \\
(0.007)\end{array}$ & $\begin{array}{l}0.011 \\
(0.007)\end{array}$ \\
\hline TFP & $\begin{array}{l}-0.119 * \\
(0.066)\end{array}$ & $\begin{array}{l}-0.206^{* * * *} \\
(0.068)\end{array}$ & $\begin{array}{l}-0.100 \\
(0.073)\end{array}$ & $\begin{array}{l}-0.168 * * \\
(0.074)\end{array}$ & $\begin{array}{l}-0.144 * * \\
(0.068)\end{array}$ & $\begin{array}{l}-0.193 * * \\
(0.074)\end{array}$ \\
\hline $\mathrm{HC}$ & $\begin{array}{l}-0.104 * * * \\
(0.029)\end{array}$ & $\begin{array}{l}-0.133 \text { *** } \\
(0.028)\end{array}$ & $\begin{array}{l}-0.101 * * * \\
(0.028)\end{array}$ & $\begin{array}{l}-0.124 * * * \\
(0.029)\end{array}$ & $\begin{array}{l}-0.119 * * * \\
(0.029)\end{array}$ & $\begin{array}{l}-0.136^{* * * *} \\
(0.031)\end{array}$ \\
\hline TFP*HC & $\begin{array}{l}0.026 \\
(0.026)\end{array}$ & $\begin{array}{l}0.063 * * \\
(0.027)\end{array}$ & $\begin{array}{l}0.019 \\
(0.029)\end{array}$ & $\begin{array}{l}0.048 \\
(0.030)\end{array}$ & $\begin{array}{l}0.030 \\
(0.027)\end{array}$ & $\begin{array}{l}0.050^{*} \\
(0.029)\end{array}$ \\
\hline Log GDP & $\begin{array}{l}0.035 * * \\
(0.015)\end{array}$ & $\begin{array}{l}0.158 * * * \\
(0.040)\end{array}$ & $\begin{array}{l}0.039 * * \\
(0.014)\end{array}$ & $\begin{array}{l}0.142 * * * \\
(0.029)\end{array}$ & $\begin{array}{l}0.037 * * \\
(0.016)\end{array}$ & $\begin{array}{l}0.108^{* * *} * \\
(0.036)\end{array}$ \\
\hline $\log \mathrm{GDP}^{\wedge} 2$ & & $\begin{array}{l}-0.018 \text { *** } \\
(0.005)\end{array}$ & & $\begin{array}{l}-0.015^{* * * *} \\
(0.004)\end{array}$ & & $\begin{array}{l}-0.010 * * \\
(0.004)\end{array}$ \\
\hline UNEMP & $\begin{array}{l}-0.002 * * * \\
(0.000)\end{array}$ & $\begin{array}{l}-0.002 \text { *** } \\
(0.000)\end{array}$ & $\begin{array}{l}-0.002 * * * \\
(0.000)\end{array}$ & $\begin{array}{l}-0.002 * * * \\
(0.000)\end{array}$ & $\begin{array}{l}-0.002 * * * \\
(0.000)\end{array}$ & $\begin{array}{l}-0.002 * * * \\
(0.000)\end{array}$ \\
\hline LABFORCE & $\begin{array}{l}-0.001 * \\
(0.000)\end{array}$ & $\begin{array}{l}-0.000 \\
(0.000)\end{array}$ & $\begin{array}{l}-0.001^{* *} \\
(0.000)\end{array}$ & $\begin{array}{l}-0.001 * \\
(0.000)\end{array}$ & $\begin{array}{l}-0.001 \\
(0.000)\end{array}$ & $\begin{array}{l}-0.001 \\
(0.000)\end{array}$ \\
\hline INT & $\begin{array}{l}0.000 * * \\
(0.000)\end{array}$ & $\begin{array}{l}0.000 * * \\
(0.000)\end{array}$ & $\begin{array}{l}0.000 * * \\
(0.000)\end{array}$ & $\begin{array}{l}0.000 * * \\
(0.000)\end{array}$ & $\begin{array}{l}0.000 * * \\
(0.000)\end{array}$ & $\begin{array}{l}0.000 * * \\
(0.000)\end{array}$ \\
\hline CRISIS & $\begin{array}{l}-0.009 * * * \\
(0.002)\end{array}$ & $\begin{array}{l}-0.009 \text { *** } \\
(0.002)\end{array}$ & $\begin{array}{l}-0.009 * * * \\
(0.002)\end{array}$ & $\begin{array}{l}-0.008 * * * \\
(0.002)\end{array}$ & $\begin{array}{l}-0.010 * * * \\
(0.002)\end{array}$ & $\begin{array}{l}-0.010 * * * \\
(0.002)\end{array}$ \\
\hline Constant & $\begin{array}{l}0.764 * * * \\
(0.084)\end{array}$ & $\begin{array}{l}0.610^{* * *} * \\
(0.108)\end{array}$ & $\begin{array}{l}0.747 * * * \\
(0.084)\end{array}$ & $\begin{array}{l}0.618 * * * \\
(0.093)\end{array}$ & $\begin{array}{l}0.791 * * * \\
(0.081)\end{array}$ & $\begin{array}{l}0.704^{* * * *} \\
(0.087)\end{array}$ \\
\hline Country & Yes & Yes & Yes & Yes & Yes & Yes \\
\hline Year & Yes & Yes & Yes & Yes & Yes & Yes \\
\hline No. of Observations & 1,029 & 1,029 & 1,029 & 1,029 & 1,029 & 1,029 \\
\hline R-squared & 0.3057 & 0.3121 & 0.3076 & 0.3122 & 0.2960 & 0.2983 \\
\hline
\end{tabular}

Note: $* * * \mathrm{p}<0.01, * * \mathrm{p}<0.05,{ }^{*} \mathrm{p}<0.1$ 
Table 2. Estimation in first differences (dependent variable: first difference of labor share of income)

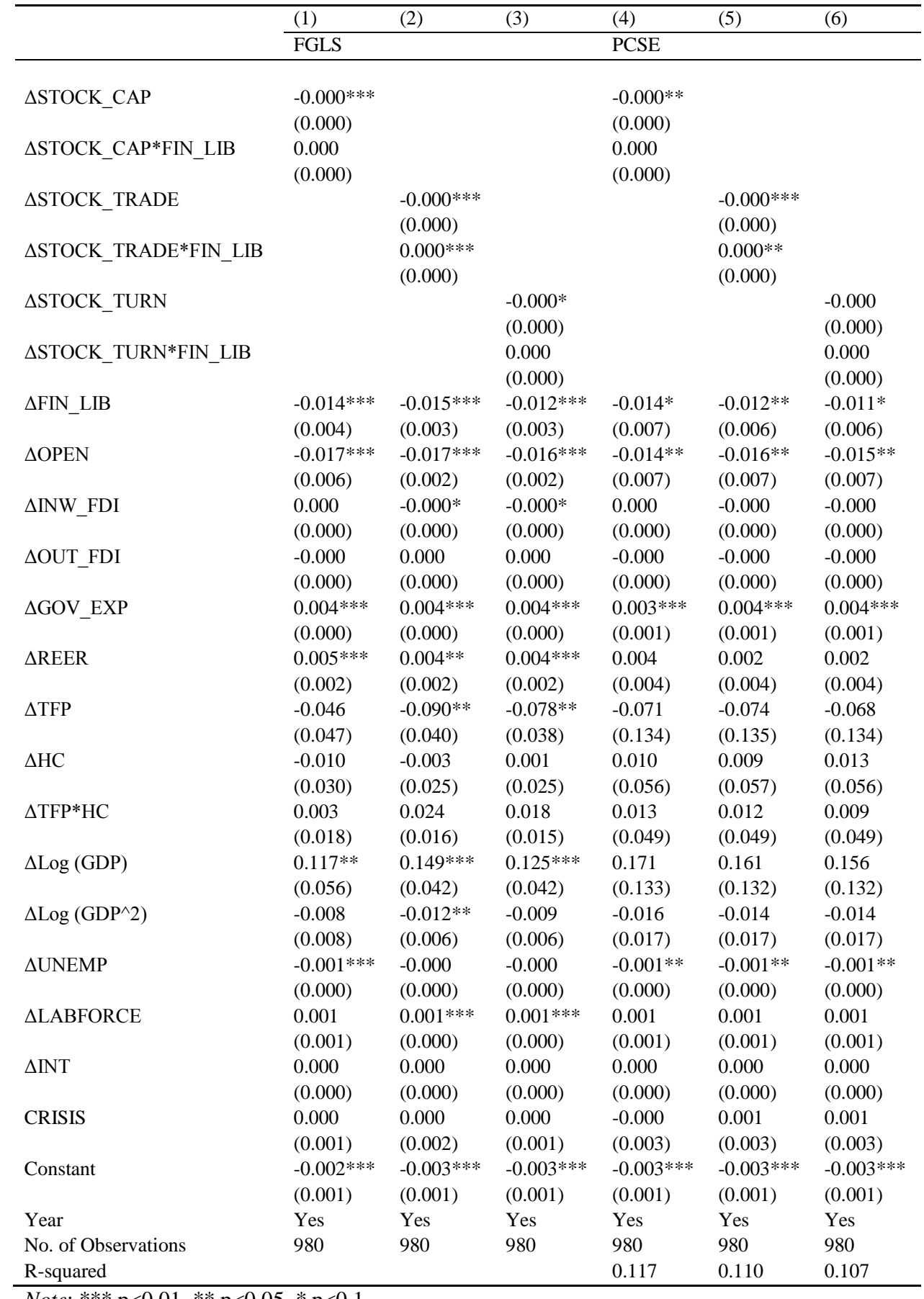

Note: $* * * \mathrm{p}<0.01, * * \mathrm{p}<0.05, * \mathrm{p}<0.1$ 
Second, globalization indicators are also proxied by FDI inflows and FDI outflows, each divided by GDP. A first glance at the empirical results reveals a negative correlation of labor's share with the FDI inflows. Here, this result is consistent with our hypothetical structure and other studies in which the labor markets and, more specifically the wage levels are being much open to detrimental effects of a rise in the scale of multinational and transnational firms in an aggregate economy. For instance, Herzer and Nunnenkamp's (2013) findings point out that the long-run effects of FDI on income inequality, on average, are negative. In addition, $\mathrm{Wu}$ and $\mathrm{Hsu}$ (2012) find a similar result that an increase in FDI leads to an unequal distribution of income and support the results of Basu and Guariglia (2007). Based on income shares of labor, Kristal (2010) argues that FDI inflows have negative effect on wages in the short-run, particularly through lowering employment level and compensations, which is rooted in multinational firms' common practice of flexible employment strategy adopted by local firms as well. However, the FDI inflows are partially significant in baseline and first-difference specifications, though it shows the expected hypothesized results with a negative sign.

Third, the next variable of globalization - FDI outflows as a share of GDP - is not significant under the baseline estimations. One of the major reasons may depend on data structure, which covers both developed and developing countries as homogeneous, though they have heterogeneous country-specific characteristics. However, the insignificant effects in other specifications do not necessarily mean that FDI outflows have no impact on the labor's share at all. As Dünhaupt (2017: 297) classifies, there might be two ways in which the labor share of national income can be affected by FDI outflows. First, the outsourced well-paid manufacturing jobs can be compensated by more supervisory jobs. Second, the threat effect might not be accounted for the data, which underestimates the actual effect of FDI outflows on income disparities.

Turning to the last variable of globalization, I find that financial openness harms the labor's share in almost all specifications. This is an unexpected result for the conventional wisdom since their arguments follow the idea that a more open financial system provides the necessary amount of resources for investments, reduces the cost of capital and raises the level of GDP per capita. However, other studies find that more open financial regime allows financially constrained firms to increase their amount of capital through external channels thus leads a rise in relative demand for skilled labor, which is assumed as a complement for capital, resulting in higher wage inequality. In this regard, this is particularly occurred due to a decrease in the bargaining power of labor (Bentolila and Saint-Paul, 2003; Harrison, 2005; Jayadev, 2007).

To capture the effects of a change in the bargaining power of workers, I use two kinds of variables - unemployment rate and labor force participation rate. Although distributional outcomes are compatible with the hypothesized relationship, the coefficient of labor force participation rate is insignificant in many specifications. One potential reason may be found in its controversial feature in which it includes both employment and unemployment data, and the other may be considered due to a higher deviation of data among sample countries. However, as expected, the unemployment rate is significant in almost all regressions and negatively correlated to the labor's share. Indeed, this result provides to make an argument that the firms become more dominant on wage reduction and hence they create downward pressure on the wage levels in periods when the labor 
supply is high relative to the labor demand. Therefore, the firms intend to employ cheap labor to benefit from their strong bargaining position against labor.

The main feature and the aim of this study are to show that the financialization variables have a negative effect on the labor's share, in control of the other variables, especially the bargaining power of labor. Regarding the financialization variables, the results are, to a large extent, consistent with the theoretical model. Although the interaction term of financialization and financial openness is not significant in many specifications, the partial effects of these variables exhibit a robust pattern. In particular, the distributional consequences of financialization measures that relate to the labor's share are consistent with the hypothesized relationship in which each variable has a significant and negative effect on the labor share of national income.

The negative consequences of financialization on labor's share may be discussed through interest rates and capital flows, in control of the financial liberalization. This means that there may be both direct and indirect links between these two variables. On the one hand, the direct link may have a positive effect on the labor's share by way of reducing the prices of goods relative to nominal wages. Increases in real interest rates may lead to a simultaneous increase in the flows of bonds and stocks and thereby the money demand. This results in a decrease in the level of the firm's investment and capital accumulation coupled with a decrease in effective demand. According to the KaldorRobinson model of distribution and growth, this also results in an increase in labor's share against the profit's share, particularly due to a fall in the prices of goods relative to nominal wages (Hein, 2008).

On the other hand, the labor's share may be negatively affected by an indirect link in case of a decrease in capital accumulation. First, the increasing tendency of nonfinancial firms towards more finance-led investments relative to real investments can lead to a decrease in employment level in parallel to the reduction in total investment. This may then lead to the erosion of bargaining position of labor against capital along with an increase in unemployed people. Therefore, it creates downward pressure on nominal wages and reduces the labor share accruing in national income in favor of the profit share. Second, the real interest rate may have an increasing tendency in line with more open financial channels thus stimulates an increase in capital inflows. It is possible that the speculative motives in financial transactions can be exacerbated which strengths the possibility of the emergence of economic booms and busts. If this is such a case, the aggregate economic system will be more crisis-prone and unstable to the capital outflows. All in all, if the negative effects of indirect links outweigh the direct channels of influence, the labor's share will be in a downward trend in favor of the profit's share.

The empirical results in Table 1 and Table 2 confirm these hypothesized relationships. While financialization variables have negative and significant effects on the labor share of national income, the effects of real interest rate are positive and also significant. Which of these channels are dominant on changing income shares primarily depends on each country's socio-economic structure and, more specifically to their strengths of labor market policies and conditions, in control of other factors. In addition, related to the indirect channel, the increasing scale of available resources along with more liberalized financial system and thereby increasing rate of capital inflows should be evaluated in terms of how these resources are allocated in the economic system. The interaction 
terms of financialization and financial liberalization measure this case and show that there are positive correlations with the labor's share. This is an expected result since more open financial system coupled with strong stock markets may possibly increase the investment motives and thus create an upward pressure on labor demand and nominal wages, which increases the labor's share. However, in this regard, the basic question is how these resources are allocated thus the legal framework of the financialization in terms of stock markets has giant importance along with the financial liberalization process. $^{19}$

The distributional consequences of macroeconomic indicators, including the government expenditures and real exchange rate stability, as hypothesized, are positive for the labor's share. First, higher government expenditure as a share of GDP means a higher share of labor income. Second, more stable and less surging exchange rates provide a safe place for foreign capital and positively influence the investment strategies. Preoccupation with exchange rate stability can exacerbate the outflowing tendency of capital abroad and thus can reduce the available resources for new investment plans through negatively affecting the amount of money supply. In this regard, the nominal wages start to fall in consequence of a decrease in the volume of investment and thereby in the employment level, which then reduces the labor's share.

Finally, identification of the causal effects of another macroeconomic variable - log of GDP per capita and its square - are mixed. While in the early stages of development, market forces satisfy the needs of workers and create new opportunities both for capital and labor, but the later phases squeeze these favorable courses, especially for the labor's income. However, this not necessarily surprising given the fact that the development path initially creates new employment opportunities for those who are unemployed through new investment strategies. Both in level and first-difference estimations, this hypothesis is significant. A plausible explanation is that economic progress favors the conditions of total workforce in case of an increasing scale of investments at the initial phases of the development in which the workers benefit from the industrialization, irrespective of their skill composition. However, the distinction between skilled and unskilled characteristics of workers become to be perceived more in the recruitment process at the later phases of the development. Hence, the wage dispersion between these two categories of workers will be much higher. Workers who are equipped with higher education will begin to earn relatively more than unskilled workers. Therefore, the intra-

\footnotetext{
${ }^{19}$ However, note that the key indicator in this estimations is the bargaining power measures in which it creates different outcomes for the effects of financialization variables proxied by the stock market indicators and pure-financial indicators on the labor share of income. Whereas the estimation results provided through the use of stock market variables show that the financialization has a negative effect on the labor share of income due to differing bargaining power of labor over time, pure-financial transactions can contribute GDP but may also contradict with a higher level of unequal distribution of income. Therefore, to understand the negative relationship between financialization and labor share of income, the effects of changing bargaining positions between capital and labor should be added into the analysis. If this is not the case, the effects of pure-financial transactions on aggregate economic conditions will inaccurately be evaluated in the long-run thus will create logical fallacy on income distribution.
} 
class dynamics of any country where the divergence of skill composition is too high will unfavorably affect the unskilled workers, and also they will possibly be unemployed in the long-run. In this regard, if the labor's share is biased towards more unskilled workers, the distributional effects will favor the profits.

To measure the technical efficiency and the effects of skill-biased technical change, I use the variables of welfare-relevant TFP and human capital, respectively. In addition, the interaction term of these variables is used to measure their synthetic effects on labor's share. The empirical outcomes are not surprising at all. The partial effects of two variables on income distribution are negative and significant in almost all specifications. These results reflect the changing pattern of an increasing gap between productivity and the real wages after the 1980s. However, the coefficient of the interaction term is positive and significant. It suggests that the returns of human capital particularly depend on productivity growth. In other words, workers who have a higher level of human capital increasingly benefit from enhanced productivity gains. In the absence of this case, the productivity gains are distributed in favor of the capital and thus raise the profit share. ${ }^{20}$

The following regressions are based on the examination of robustness issues in terms of three cases. First, although the financialization indicators are not changed, the globalization is measured by a larger scale of variables in the context of economic globalization deduced from the KOF Globalization database in Tables 3 and 4. Second, Table 5 applies the lagged values of the explanatory variables within a similar context represented in the baseline specifications. Third, Table 6 considers the three-year averages of the data.

As a test of robustness, Tables 3 and 4 repeat the previous model by using the same theoretical background but changing the globalization variables with a larger scale economic globalization dataset. Each estimation result from Column (1) to (12) confirms the benchmark estimates. Hence, the significance of the theoretical model is validated even in a large dataset comprising the variables subject to economic globalization. To control for potential endogeneity, Table 5 introduces the lagged values of the explanatory variables. Column (1) to (6) in each Table initiates the empirical outcomes which are compatible with the benchmark estimates. The coefficients of financialization variables are still negative and significant in most specifications. ${ }^{21}$ Moreover, the bargaining power measure, namely the unemployment rate, is negatively correlated with the labor share in all regressions while the variable of labor force participation rate is insignificant. The estimation results, regarding the bargaining power of labor, with lagged exogenous variables, find unemployment rate and the labor force participation rate to affect the labor share even though the latter variable is insignificant in most specifications. Finally, Table 6 regards the empirical results with three-year averaged data to observe whether or not the effects are long-lasting and or subject to the temporary shocks. In this

\footnotetext{
${ }^{20}$ For more information on technical details of the relationship between human capital and productivity growth see Abel et al. (2012); Schwerdt and Turunen (2007); Söderbom and Teal (2004).

${ }^{21}$ Since the number of observations reduces by further time lags which may produce biased estimations, the results obtained in Table 5 are on the basis of one lag of the variables.
} 
regard, most of the previous results are robust and thus indicate that the long-run effects are decisive. The results are thus sound that many of the variables are still significant and have an impact on labor share of national income, which then strengths the integrity of hypothesized relationships.

Table 3. Robustness analysis (dependent variable: labor share of income)

\begin{tabular}{|c|c|c|c|c|c|c|}
\hline & $(1)$ & (2) & (3) & (4) & $(5)$ & (6) \\
\hline STOCK_CAP & $\begin{array}{l}-0.000^{* *} \\
(0.000)\end{array}$ & & & $\begin{array}{l}-0.001 * * \\
(0.000)\end{array}$ & & \\
\hline STOCK_CAP*ECON_GLOB & $\begin{array}{l}0.000^{*} \\
(0.000)\end{array}$ & & & $\begin{array}{l}0.000 * * \\
(0.000)\end{array}$ & & \\
\hline STOCK_TRADE & & $\begin{array}{l}-0.001^{* * * *} \\
(0.000)\end{array}$ & & & $\begin{array}{l}-0.001 * * * \\
(0.000)\end{array}$ & \\
\hline STOCK_TRADE*ECON_GLOB & & $\begin{array}{l}0.000 * * * \\
(0.000)\end{array}$ & & & $\begin{array}{l}0.000 * * * \\
(0.000)\end{array}$ & \\
\hline STOCK_TURN & & & $\begin{array}{l}-0.000 \\
(0.000)\end{array}$ & & & $\begin{array}{l}-0.000 * \\
(0.000)\end{array}$ \\
\hline STOCK_TURN*ECON_GLOB & & & $\begin{array}{l}0.000 \\
(0.000)\end{array}$ & & & $\begin{array}{l}0.000 \\
(0.000)\end{array}$ \\
\hline ECON_GLOB & $\begin{array}{l}-0.002 * * * \\
(0.000)\end{array}$ & $\begin{array}{l}-0.002 * * * \\
(0.000)\end{array}$ & $\begin{array}{l}-0.002 * * * \\
(0.000)\end{array}$ & $\begin{array}{l}-0.001^{* * *} \\
(0.000)\end{array}$ & $\begin{array}{l}-0.001 * * * \\
(0.000)\end{array}$ & $\begin{array}{l}-0.001 * * * \\
(0.000)\end{array}$ \\
\hline GOV_EXP & $\begin{array}{l}0.002 * * \\
(0.001)\end{array}$ & $\begin{array}{l}0.002 * * * \\
(0.001)\end{array}$ & $\begin{array}{l}0.002 * * * \\
(0.001)\end{array}$ & $\begin{array}{l}0.003 * * * \\
(0.001)\end{array}$ & $\begin{array}{l}0.003 * * * \\
(0.001)\end{array}$ & $\begin{array}{l}0.003 * * * \\
(0.001)\end{array}$ \\
\hline REER & $\begin{array}{l}0.009 \\
(0.005)\end{array}$ & $\begin{array}{l}0.007 \\
(0.006)\end{array}$ & $\begin{array}{l}0.009 \\
(0.005)\end{array}$ & $\begin{array}{l}0.012 * \\
(0.007)\end{array}$ & $\begin{array}{l}0.010 \\
(0.007)\end{array}$ & $\begin{array}{l}0.011^{*} \\
(0.007)\end{array}$ \\
\hline TFP & $\begin{array}{l}-0.041 * * * \\
(0.012)\end{array}$ & $\begin{array}{l}-0.037 * * * \\
(0.013)\end{array}$ & $\begin{array}{l}-0.054 * * * \\
(0.010)\end{array}$ & $\begin{array}{l}-0.260 * * * \\
(0.060)\end{array}$ & $\begin{array}{l}-0.235^{* * *} * \\
(0.065)\end{array}$ & $\begin{array}{l}-0.268 * * * \\
(0.059)\end{array}$ \\
\hline $\mathrm{HC}$ & & & & $\begin{array}{l}-0.141^{* * * *} \\
(0.023)\end{array}$ & $\begin{array}{l}-0.132 * * * \\
(0.023)\end{array}$ & $\begin{array}{l}-0.140 * * * \\
(0.022)\end{array}$ \\
\hline TFP*HC & & & & $\begin{array}{l}0.092 * * * \\
(0.024)\end{array}$ & $\begin{array}{l}0.081 * * * \\
(0.026)\end{array}$ & $\begin{array}{l}0.091 * * * \\
(0.023)\end{array}$ \\
\hline $\log (\mathrm{GDP})$ & & & & $\begin{array}{l}0.215 * * * \\
(0.051)\end{array}$ & $\begin{array}{l}0.195 * * * \\
(0.039)\end{array}$ & $\begin{array}{l}0.161 * * * \\
(0.041)\end{array}$ \\
\hline $\log \left(\mathrm{GDP}^{\wedge} 2\right)$ & & & & $\begin{array}{l}-0.028 * * * \\
(0.006)\end{array}$ & $\begin{array}{l}-0.025 * * * \\
(0.005)\end{array}$ & $\begin{array}{l}-0.021 * * * \\
(0.005)\end{array}$ \\
\hline UNEMP & $\begin{array}{l}-0.002 * * * \\
(0.000)\end{array}$ & $\begin{array}{l}-0.002^{* * * *} \\
(0.001)\end{array}$ & $\begin{array}{l}-0.002 * * * \\
(0.000)\end{array}$ & $\begin{array}{l}-0.002 * * * \\
(0.000)\end{array}$ & $\begin{array}{l}-0.001 * * * \\
(0.000)\end{array}$ & $\begin{array}{l}-0.002 * * * \\
(0.000)\end{array}$ \\
\hline LABFORCE & $\begin{array}{l}-0.001^{* *} \\
(0.000)\end{array}$ & $\begin{array}{l}-0.001^{* * * *} \\
(0.000)\end{array}$ & $\begin{array}{l}-0.001 * * \\
(0.000)\end{array}$ & $\begin{array}{l}-0.000 \\
(0.000)\end{array}$ & $\begin{array}{l}-0.001 * \\
(0.000)\end{array}$ & $\begin{array}{l}-0.000 \\
(0.000)\end{array}$ \\
\hline INT & $\begin{array}{l}0.000 * * * \\
(0.000)\end{array}$ & $\begin{array}{l}0.000 * * * \\
(0.000)\end{array}$ & $\begin{array}{l}0.001 * * * \\
(0.000)\end{array}$ & $\begin{array}{l}0.000 * \\
(0.000)\end{array}$ & $\begin{array}{l}0.000 * * \\
(0.000)\end{array}$ & $\begin{array}{l}0.000 * * \\
(0.000)\end{array}$ \\
\hline CRISIS & $\begin{array}{l}-0.011 * * * \\
(0.003)\end{array}$ & $\begin{array}{l}-0.011^{* * *} * \\
(0.003)\end{array}$ & $\begin{array}{l}-0.012 * * * \\
(0.003)\end{array}$ & $\begin{array}{l}-0.008 * * * \\
(0.002)\end{array}$ & $\begin{array}{l}-0.009 * * * \\
(0.002)\end{array}$ & $\begin{array}{l}-0.010 * * * \\
(0.002)\end{array}$ \\
\hline Constant & $\begin{array}{l}0.716^{* * * *} \\
(0.016)\end{array}$ & $\begin{array}{l}0.726^{* * * *} \\
(0.017)\end{array}$ & $\begin{array}{l}0.722 * * * \\
(0.019)\end{array}$ & $\begin{array}{l}0.585^{* * * *} \\
(0.112)\end{array}$ & $\begin{array}{l}0.608 * * * \\
(0.100)\end{array}$ & $\begin{array}{l}0.690 * * * \\
(0.097)\end{array}$ \\
\hline Country & Yes & Yes & Yes & Yes & Yes & Yes \\
\hline Year & Yes & Yes & Yes & Yes & Yes & Yes \\
\hline No. of Observations & 1,029 & 1,029 & 1,029 & 1,029 & 1,029 & 1,029 \\
\hline R-squared & 0.2877 & 0.2939 & 0.2809 & 0.3368 & 0.3383 & 0.3263 \\
\hline
\end{tabular}

Note: $* * * \mathrm{p}<0.01, * * \mathrm{p}<0.05, * \mathrm{p}<0.1$ 
Table 4. Robustness analysis (dependent variable: first difference of labor share of income)

\begin{tabular}{|c|c|c|c|c|c|c|}
\hline & $(1)$ & $(2)$ & $(3)$ & $(4)$ & $(5)$ & $(6)$ \\
\hline$\triangle \mathrm{STOCK} \_\mathrm{CAP}$ & $\begin{array}{l}-0.000^{* * *} \\
(0.000)\end{array}$ & $\begin{array}{l}-0.000 \\
(0.000)\end{array}$ & & & & \\
\hline$\triangle \mathrm{STOCK}$ _CAP*ECON_GLOB & $\begin{array}{l}0.000 \\
(0.000)\end{array}$ & $\begin{array}{l}0.000 \\
(0.000)\end{array}$ & & & & \\
\hline$\triangle$ STOCK_TRADE & & & $\begin{array}{l}- \\
0.000 * * * \\
(0.000)\end{array}$ & $\begin{array}{l}-0.000 \\
(0.000)\end{array}$ & & \\
\hline$\triangle$ STOCK_TRADE*ECON_GLOB & & & $\begin{array}{l}0.000^{* * *} \\
(0.000)\end{array}$ & $\begin{array}{l}0.000 \\
(0.000)\end{array}$ & & \\
\hline$\triangle$ STOCK_TURN & & & & & $\begin{array}{l}-0.000 \\
(0.000)\end{array}$ & $\begin{array}{l}-0.000 \\
(0.000)\end{array}$ \\
\hline$\triangle$ STOCK_TURN*ECON_GLOB & & & & & $\begin{array}{l}-0.000 \\
(0.000)\end{array}$ & $\begin{array}{l}0.000 \\
(0.000)\end{array}$ \\
\hline$\triangle \mathrm{ECON}$ _GLOB & $\begin{array}{l}- \\
0.001 * * * \\
(0.000)\end{array}$ & $\begin{array}{l}- \\
0.001 * * * \\
(0.000)\end{array}$ & $\begin{array}{l}- \\
0.002 * * * \\
(0.000)\end{array}$ & $\begin{array}{l}- \\
0.001 * * * \\
(0.000)\end{array}$ & $\begin{array}{l}- \\
0.001 * * * \\
(0.000)\end{array}$ & $\begin{array}{l}- \\
0.001 * * * \\
(0.000)\end{array}$ \\
\hline$\Delta \mathrm{GOV} \_\mathrm{EXP}$ & $\begin{array}{l}0.004 * * * \\
(0.000)\end{array}$ & $\begin{array}{l}0.003 * * * \\
(0.001)\end{array}$ & $\begin{array}{l}0.004 * * * \\
(0.000)\end{array}$ & $\begin{array}{l}0.003 * * * \\
(0.001)\end{array}$ & $\begin{array}{l}0.004 * * * \\
(0.000)\end{array}$ & $\begin{array}{l}0.004 * * * \\
(0.001)\end{array}$ \\
\hline$\triangle$ REER & $\begin{array}{l}0.004 * * \\
(0.002)\end{array}$ & $\begin{array}{l}0.004 \\
(0.004)\end{array}$ & $\begin{array}{l}0.004 * * * \\
(0.002)\end{array}$ & $\begin{array}{l}0.003 \\
(0.004)\end{array}$ & $\begin{array}{l}0.004 * * * \\
(0.002)\end{array}$ & $\begin{array}{l}0.003 \\
(0.004)\end{array}$ \\
\hline$\triangle \mathrm{TFP}$ & $-0.018 * *$ & -0.028 & $-0.018 * *$ & -0.032 & $-\overline{0.025 * * *}$ & -0.034 \\
\hline$\triangle \mathrm{UNEMP}$ & $\begin{array}{l}(0.008) \\
- \\
0.001 * * * \\
(0.000)\end{array}$ & $\begin{array}{l}(0.025) \\
- \\
0.002 * * * \\
(0.001)\end{array}$ & $\begin{array}{l}(0.008) \\
- \\
0.001 \text { *** } \\
(0.000)\end{array}$ & $\begin{array}{l}(0.025) \\
- \\
0.001 * * * \\
(0.001)\end{array}$ & $\begin{array}{l}(0.009) \\
- \\
0.001 * * * \\
(0.000)\end{array}$ & $\begin{array}{l}(0.025) \\
- \\
0.001 * * * \\
(0.001)\end{array}$ \\
\hline$\triangle \mathrm{LABFORCE}$ & $\begin{array}{l}0.001 * * \\
(0.000)\end{array}$ & $\begin{array}{l}0.001 \\
(0.001)\end{array}$ & $\begin{array}{l}0.000 \\
(0.001)\end{array}$ & $\begin{array}{l}0.001 \\
(0.001)\end{array}$ & $\begin{array}{l}0.000 \\
(0.001)\end{array}$ & $\begin{array}{l}0.001 \\
(0.001)\end{array}$ \\
\hline$\Delta \mathrm{INT}$ & $\begin{array}{l}0.000 \\
(0.000)\end{array}$ & $\begin{array}{l}0.000 \\
(0.000)\end{array}$ & $\begin{array}{l}0.000 \\
(0.000)\end{array}$ & $\begin{array}{l}0.000 \\
(0.000)\end{array}$ & $\begin{array}{l}0.000^{*} \\
(0.000)\end{array}$ & $\begin{array}{l}0.000 \\
(0.000)\end{array}$ \\
\hline CRISIS & $\begin{array}{l}-0.001 \\
(0.001)\end{array}$ & $\begin{array}{l}-0.001 \\
(0.002)\end{array}$ & $\begin{array}{l}0.000 \\
(0.001)\end{array}$ & $\begin{array}{l}-0.000 \\
(0.002)\end{array}$ & $\begin{array}{l}-0.000 \\
(0.001)\end{array}$ & $\begin{array}{l}-0.000 \\
(0.002)\end{array}$ \\
\hline Constant & $-0.001 *$ & -0.001 & $\begin{array}{l}- \\
0.001 * * * \\
(0.000)\end{array}$ & -0.001 & $\begin{array}{l}- \\
0.001 * * * \\
(0.000)\end{array}$ & $\begin{array}{l}-0.001 \\
(0.001)\end{array}$ \\
\hline Year & Yes & Yes & Yes & Yes & Yes & Yes \\
\hline No. of Observations & 980 & 980 & 980 & 980 & 980 & 980 \\
\hline R-squared & & 0.117 & & 0.113 & & 0.113 \\
\hline
\end{tabular}


Table 4 (cont.). Robustness analysis (dependent variable: first difference of labor share of income)

\begin{tabular}{|c|c|c|c|c|c|c|}
\hline & (7) & (8) & (9) & $(10)$ & (11) & (12) \\
\hline \multirow[t]{2}{*}{$\triangle$ STOCK_CAP } & $-0.000 * *$ & -0.000 & & & & \\
\hline & $(0.000)$ & $(0.000)$ & & & & \\
\hline \multirow[t]{2}{*}{$\triangle \mathrm{STOCK} \_\mathrm{CAP} * \mathrm{ECON} \_\mathrm{GLOB}$} & 0.000 & 0.000 & & & & \\
\hline & $(0.000)$ & $(0.000)$ & & & & \\
\hline \multirow[t]{3}{*}{$\triangle$ STOCK_TRADE } & & & - & -0.000 & & \\
\hline & & & $0.000 * * *$ & & & \\
\hline & & & $(0.000)$ & $(0.000)$ & & \\
\hline \multirow[t]{2}{*}{$\triangle$ STOCK_TRADE*ECON_GLOB } & & & $0.000 * *$ & 0.000 & & \\
\hline & & & $(0.000)$ & $(0.000)$ & & \\
\hline \multirow[t]{2}{*}{$\triangle \mathrm{STOCK} \_\mathrm{TURN}$} & & & & & 0.000 & -0.000 \\
\hline & & & & & $(0.000)$ & $(0.000)$ \\
\hline \multirow[t]{2}{*}{$\triangle$ STOCK_TURN*ECON_GLOB } & & & & & $-0.000 *$ & 0.000 \\
\hline & & & & & $(0.000)$ & $(0.000)$ \\
\hline \multirow[t]{3}{*}{$\triangle E C O N \_G L O B$} & - & - & - & - & - & - \\
\hline & $0.001 * * *$ & $0.001 * * *$ & $0.001 * * *$ & $0.001 * * *$ & $0.001 * * *$ & $0.001 * * *$ \\
\hline & $(0.000)$ & $(0.000)$ & $(0.000)$ & $(0.000)$ & $(0.000)$ & $(0.000)$ \\
\hline \multirow[t]{2}{*}{$\Delta \mathrm{GOV}$ EXP } & $0.004 * * *$ & $0.003^{* * *} *$ & $0.004 * * *$ & $0.004 * * *$ & $0.004 * * *$ & $0.004 * * *$ \\
\hline & $(0.000)$ & $(0.001)$ & $(0.000)$ & $(0.001)$ & $(0.000)$ & $(0.001)$ \\
\hline \multirow[t]{2}{*}{$\triangle \mathrm{REER}$} & $0.005 * * *$ & 0.003 & $0.004 * *$ & 0.002 & $0.004 * *$ & 0.002 \\
\hline & $(0.002)$ & $(0.004)$ & $(0.002)$ & $(0.004)$ & $(0.002)$ & $(0.004)$ \\
\hline \multirow[t]{2}{*}{$\Delta \mathrm{TFP}$} & $-0.112^{* *}$ & -0.070 & -0.055 & -0.067 & -0.050 & -0.068 \\
\hline & $(0.054)$ & $(0.134)$ & $(0.048)$ & $(0.133)$ & $(0.046)$ & $(0.133)$ \\
\hline \multirow[t]{2}{*}{$\Delta \mathrm{HC}$} & 0.010 & 0.005 & 0.008 & 0.006 & 0.012 & 0.006 \\
\hline & $(0.028)$ & $(0.055)$ & $(0.025)$ & $(0.056)$ & $(0.024)$ & $(0.055)$ \\
\hline \multirow[t]{2}{*}{$\Delta \mathrm{TFP} * \mathrm{HC}$} & 0.034 & 0.014 & 0.009 & 0.011 & 0.008 & 0.010 \\
\hline & $(0.021)$ & $(0.049)$ & $(0.019)$ & $(0.049)$ & $(0.018)$ & $(0.049)$ \\
\hline \multirow[t]{3}{*}{$\triangle \mathrm{UNEMP}$} & - & - & - & - & $-0.001 * *$ & - \\
\hline & $0.001 * * *$ & $0.001 * * *$ & $0.001 * * *$ & $0.001 * * *$ & & $0.001 * * *$ \\
\hline & $(0.000)$ & $(0.000)$ & $(0.000)$ & $(0.000)$ & $(0.000)$ & $(0.000)$ \\
\hline \multirow[t]{2}{*}{$\triangle \mathrm{LABFORCE}$} & 0.001 & 0.001 & $0.001 * *$ & 0.001 & $0.001 * *$ & 0.001 \\
\hline & $(0.000)$ & $(0.001)$ & $(0.000)$ & $(0.001)$ & $(0.000)$ & $(0.001)$ \\
\hline \multirow[t]{2}{*}{$\Delta \log (\mathrm{GDP})$} & $0.099 * *$ & 0.142 & $0.119 * *$ & 0.133 & $0.091 * *$ & 0.130 \\
\hline & $(0.042)$ & $(0.126)$ & $(0.047)$ & $(0.126)$ & $(0.045)$ & $(0.126)$ \\
\hline \multirow[t]{2}{*}{$\Delta \log \left(\mathrm{GDP}^{\wedge} 2\right)$} & $-0.010^{*}$ & -0.016 & $-0.013 * *$ & -0.015 & -0.010 & -0.014 \\
\hline & $(0.006)$ & $(0.016)$ & $(0.006)$ & $(0.016)$ & $(0.006)$ & $(0.016)$ \\
\hline \multirow[t]{2}{*}{$\Delta \mathrm{INT}$} & $0.000 * * *$ & 0.000 & $0.000 * *$ & 0.000 & $0.000 *$ & 0.000 \\
\hline & $(0.000)$ & $(0.000)$ & $(0.000)$ & $(0.000)$ & $(0.000)$ & $(0.000)$ \\
\hline \multirow[t]{2}{*}{ CRISIS } & -0.000 & -0.001 & 0.000 & -0.000 & -0.001 & -0.000 \\
\hline & $(0.001)$ & $(0.003)$ & $(0.001)$ & $(0.003)$ & $(0.001)$ & $(0.003)$ \\
\hline \multirow[t]{3}{*}{ Constant } & - & $-0.002 * *$ & - & $-0.002^{* *}$ & - & $-0.002 *$ \\
\hline & $0.002 * * *$ & & $0.002 * * *$ & & $0.002 * * *$ & \\
\hline & $(0.001)$ & $(0.001)$ & $(0.001)$ & $(0.001)$ & $(0.001)$ & $(0.001)$ \\
\hline Year & Yes & Yes & Yes & Yes & Yes & Yes \\
\hline No. of Observations & 980 & 980 & 980 & 980 & 980 & 980 \\
\hline R-squared & & 0.126 & & 0.121 & & 0.120 \\
\hline
\end{tabular}

Note: $* * * \mathrm{p}<0.01, * * \mathrm{p}<0.05, * \mathrm{p}<0.1$ 
Table 5. Estimations in lagged values (dependent variable: lagged values of labor share of income)

\begin{tabular}{|c|c|c|c|c|c|c|}
\hline & (1) & (2) & (3) & (4) & (5) & (6) \\
\hline STOCK_CAP & $\begin{array}{l}-0.000^{* * * *} \\
(0.000)\end{array}$ & & & $\begin{array}{l}-0.000 * * \\
(0.000)\end{array}$ & & \\
\hline STOCK_CAP*FIN_LIB & $\begin{array}{l}0.000 * * * \\
(0.000)\end{array}$ & & & $\begin{array}{l}0.000 \\
(0.000)\end{array}$ & & \\
\hline STOCK_TRADE & & $\begin{array}{l}-0.001 \text { *** } \\
(0.000)\end{array}$ & & & $\begin{array}{l}-0.001 * * * \\
(0.000)\end{array}$ & \\
\hline STOCK_TRADE*FIN_LIB & & $\begin{array}{l}0.001 * * * \\
(0.000)\end{array}$ & & & $\begin{array}{l}0.000 * * * \\
(0.000)\end{array}$ & \\
\hline STOCK_TURN & & & $\begin{array}{l}-0.000 \\
(0.000)\end{array}$ & & & $\begin{array}{l}-0.000 \\
(0.000)\end{array}$ \\
\hline STOCK_TURN*FIN_LIB & & & $\begin{array}{l}-0.000 \\
(0.000)\end{array}$ & & & $\begin{array}{l}-0.000 \\
(0.000)\end{array}$ \\
\hline FIN_LIB & $\begin{array}{l}-0.011^{* * *} \\
(0.003)\end{array}$ & $\begin{array}{l}-0.011^{* * *} \\
(0.003)\end{array}$ & $\begin{array}{l}-0.001 \\
(0.004)\end{array}$ & $\begin{array}{l}-0.005 \\
(0.004)\end{array}$ & $\begin{array}{l}-0.006 * * \\
(0.003)\end{array}$ & $\begin{array}{l}0.002 \\
(0.003)\end{array}$ \\
\hline OPEN & $\begin{array}{l}-0.028 * * * \\
(0.008)\end{array}$ & $\begin{array}{l}-0.029 * * * \\
(0.008)\end{array}$ & $\begin{array}{l}-0.029 * * * \\
(0.008)\end{array}$ & $\begin{array}{l}-0.021 * * * \\
(0.005)\end{array}$ & $\begin{array}{l}-0.023 * * * \\
(0.005)\end{array}$ & $\begin{array}{l}-0.024 * * * \\
(0.005)\end{array}$ \\
\hline INW_FDI & $\begin{array}{l}-0.000 \\
(0.000)\end{array}$ & $\begin{array}{l}-0.000 \\
(0.000)\end{array}$ & $\begin{array}{l}-0.000^{*} \\
(0.000)\end{array}$ & $\begin{array}{l}-0.000 \\
(0.000)\end{array}$ & $\begin{array}{l}-0.000 \\
(0.000)\end{array}$ & $\begin{array}{l}-0.000 \\
(0.000)\end{array}$ \\
\hline OUT_FDI & $\begin{array}{l}0.000 \\
(0.000)\end{array}$ & $\begin{array}{l}0.000 \\
(0.000)\end{array}$ & $\begin{array}{l}0.000 \\
(0.000)\end{array}$ & $\begin{array}{l}0.000 \\
(0.000)\end{array}$ & $\begin{array}{l}0.000 \\
(0.000)\end{array}$ & $\begin{array}{l}0.000 \\
(0.000)\end{array}$ \\
\hline GOV_EXP & $\begin{array}{l}0.003 \text { *** } \\
(0.001)\end{array}$ & $\begin{array}{l}0.003 * * * \\
(0.001)\end{array}$ & $\begin{array}{l}0.003 * * * \\
(0.001)\end{array}$ & $\begin{array}{l}0.004 * * * \\
(0.001)\end{array}$ & $\begin{array}{l}0.004 * * * \\
(0.001)\end{array}$ & $\begin{array}{l}0.004^{* * * *} \\
(0.001)\end{array}$ \\
\hline REER & $\begin{array}{l}0.009 \\
(0.006)\end{array}$ & $\begin{array}{l}0.006 \\
(0.006)\end{array}$ & $\begin{array}{l}0.009 \\
(0.006)\end{array}$ & $\begin{array}{l}0.011 \\
(0.007)\end{array}$ & $\begin{array}{l}0.008 \\
(0.007)\end{array}$ & $\begin{array}{l}0.010 \\
(0.007)\end{array}$ \\
\hline TFP & $\begin{array}{l}-0.043 * * * \\
(0.015)\end{array}$ & $\begin{array}{l}-0.036^{* *} \\
(0.015)\end{array}$ & $\begin{array}{l}-0.068 * * * \\
(0.012)\end{array}$ & $\begin{array}{l}-0.198 * * * \\
(0.069)\end{array}$ & $\begin{array}{l}-0.165 * * \\
(0.077)\end{array}$ & $\begin{array}{l}-0.188 * * \\
(0.077)\end{array}$ \\
\hline $\mathrm{HC}$ & & & & $\begin{array}{l}-0.137 * * * \\
(0.029)\end{array}$ & $\begin{array}{l}-0.128 * * * \\
(0.030)\end{array}$ & $\begin{array}{l}-0.140 \text { *** } \\
(0.032)\end{array}$ \\
\hline TFP*HC & & & & $\begin{array}{l}0.060 * * \\
(0.028)\end{array}$ & $\begin{array}{l}0.047 \\
(0.031)\end{array}$ & $\begin{array}{l}0.050 \\
(0.031)\end{array}$ \\
\hline $\log (\mathrm{GDP})$ & & & & $\begin{array}{l}0.140 * * * \\
(0.037)\end{array}$ & $\begin{array}{l}0.133 * * * \\
(0.031)\end{array}$ & $\begin{array}{l}0.097 * * \\
(0.038)\end{array}$ \\
\hline $\log \left(\mathrm{GDP}^{\wedge} 2\right)$ & & & & $\begin{array}{l}-0.016^{* * * *} \\
(0.005)\end{array}$ & $\begin{array}{l}-0.014 * * * \\
(0.004)\end{array}$ & $\begin{array}{l}-0.009 * * \\
(0.004)\end{array}$ \\
\hline UNEMP & $\begin{array}{l}-0.003 * * * \\
(0.000)\end{array}$ & $\begin{array}{l}-0.003^{* * *} * \\
(0.001)\end{array}$ & $\begin{array}{l}-0.003^{* * * *} \\
(0.000)\end{array}$ & $\begin{array}{l}-0.002^{* * * *} \\
(0.000)\end{array}$ & $\begin{array}{l}-0.002 * * * \\
(0.000)\end{array}$ & $\begin{array}{l}-0.002 * * * \\
(0.000)\end{array}$ \\
\hline LABFORCE & $\begin{array}{l}-0.001 \text { *** } \\
(0.000)\end{array}$ & $\begin{array}{l}-0.001 \text { *** } \\
(0.000)\end{array}$ & $\begin{array}{l}-0.001 * * \\
(0.000)\end{array}$ & $\begin{array}{l}-0.000 \\
(0.000)\end{array}$ & $\begin{array}{l}-0.001 \\
(0.000)\end{array}$ & $\begin{array}{l}-0.000 \\
(0.000)\end{array}$ \\
\hline INT & $\begin{array}{l}0.000 * * * \\
(0.000)\end{array}$ & $\begin{array}{l}0.000 \text { *** } \\
(0.000)\end{array}$ & $\begin{array}{l}0.001 * * * \\
(0.000)\end{array}$ & $\begin{array}{l}0.000 * \\
(0.000)\end{array}$ & $\begin{array}{l}0.000 * \\
(0.000)\end{array}$ & $\begin{array}{l}0.000 * * \\
(0.000)\end{array}$ \\
\hline CRISIS & $\begin{array}{l}-0.011 * * \\
(0.004)\end{array}$ & $\begin{array}{l}-0.010 * * \\
(0.004)\end{array}$ & $\begin{array}{l}-0.012 * * \\
(0.004)\end{array}$ & $\begin{array}{l}-0.008 * * * \\
(0.002)\end{array}$ & $\begin{array}{l}-0.008 * * * \\
(0.002)\end{array}$ & $\begin{array}{l}-0.009 * * * \\
(0.003)\end{array}$ \\
\hline Constant & $\begin{array}{l}0.659 * * * \\
(0.022)\end{array}$ & $\begin{array}{l}0.662^{* * * *} \\
(0.020)\end{array}$ & $\begin{array}{l}0.669 * * * \\
(0.026)\end{array}$ & $\begin{array}{l}0.645 * * * \\
(0.107)\end{array}$ & $\begin{array}{l}0.635 * * * \\
(0.101)\end{array}$ & $\begin{array}{l}0.726^{* * * *} \\
(0.090)\end{array}$ \\
\hline Country & Yes & Yes & Yes & Yes & Yes & Yes \\
\hline Year & Yes & Yes & Yes & Yes & Yes & Yes \\
\hline No. of Observations & 980 & 980 & 980 & 980 & 980 & 980 \\
\hline R-squared & 0.2612 & 0.2676 & 0.2354 & 0.3195 & 0.3230 & 0.3101 \\
\hline
\end{tabular}


Table 6. Estimations in 3-year average (dependent variable: 3-year average of labor share of income)

\begin{tabular}{|c|c|c|c|c|c|c|}
\hline & (1) & (2) & (3) & (4) & $(5)$ & (6) \\
\hline STOCK_CAP & $\begin{array}{l}-0.001 \text { *** } \\
(0.000)\end{array}$ & $\begin{array}{l}-0.000^{* *} \\
(0.000)\end{array}$ & & & & \\
\hline STOCK_CAP*FIN_LIB & $\begin{array}{l}0.000 * * * \\
(0.000)\end{array}$ & $\begin{array}{l}0.000 \\
(0.000)\end{array}$ & & & & \\
\hline STOCK_TRADE & & & $\begin{array}{l}-0.001 * * * \\
(0.000)\end{array}$ & $\begin{array}{l}-0.001 * * * \\
(0.000)\end{array}$ & & \\
\hline STOCK_TRADE*FIN_LIB & & & $\begin{array}{l}0.001 * * * \\
(0.000)\end{array}$ & $\begin{array}{l}0.001 * * \\
(0.000)\end{array}$ & & \\
\hline STOCK_TURN & & & & & $\begin{array}{l}-0.000 \\
(0.000)\end{array}$ & $\begin{array}{l}-0.000 \\
(0.000)\end{array}$ \\
\hline STOCK_TURN*FIN_LIB & & & & & $\begin{array}{l}-0.000 \\
(0.000)\end{array}$ & $\begin{array}{l}-0.000 \\
(0.000)\end{array}$ \\
\hline FIN_LIB & $\begin{array}{l}-0.006 * * \\
(0.002)\end{array}$ & $\begin{array}{l}-0.007 \\
(0.006)\end{array}$ & $\begin{array}{l}-0.007 * \\
(0.004)\end{array}$ & $\begin{array}{l}-0.006^{* * *} \\
(0.001)\end{array}$ & $\begin{array}{l}0.004 \\
(0.006)\end{array}$ & $\begin{array}{l}0.004 \\
(0.003)\end{array}$ \\
\hline OPEN & $\begin{array}{l}-0.033^{* * * *} \\
(0.008)\end{array}$ & $\begin{array}{l}-0.025^{* * *} \\
(0.005)\end{array}$ & $\begin{array}{l}-0.034 * * * \\
(0.009)\end{array}$ & $\begin{array}{l}-0.028 * * * \\
(0.006)\end{array}$ & $\begin{array}{l}-0.034 * * \\
(0.010)\end{array}$ & $\begin{array}{l}-0.030 \text { *** } \\
(0.006)\end{array}$ \\
\hline INW_FDI & $\begin{array}{l}-0.001 \\
(0.001)\end{array}$ & $\begin{array}{l}-0.001 \\
(0.001)\end{array}$ & $\begin{array}{l}-0.001 \\
(0.001)\end{array}$ & $\begin{array}{l}-0.001 \\
(0.001)\end{array}$ & $\begin{array}{l}-0.001 \\
(0.001)\end{array}$ & $\begin{array}{l}-0.001 \\
(0.001)\end{array}$ \\
\hline OUT_FDI & $\begin{array}{l}0.000 \\
(0.001)\end{array}$ & $\begin{array}{l}0.001 \\
(0.000)\end{array}$ & $\begin{array}{l}0.001 \\
(0.001)\end{array}$ & $\begin{array}{l}0.001 \\
(0.001)\end{array}$ & $\begin{array}{l}0.001 \\
(0.001)\end{array}$ & $\begin{array}{l}0.001 \\
(0.001)\end{array}$ \\
\hline GOV_EXP & $\begin{array}{l}0.002 * * \\
(0.001)\end{array}$ & $\begin{array}{l}0.003 * * * \\
(0.001)\end{array}$ & $\begin{array}{l}0.003 * * * \\
(0.001)\end{array}$ & $\begin{array}{l}0.003 * * * \\
(0.001)\end{array}$ & $\begin{array}{l}0.003 * * \\
(0.001)\end{array}$ & $\begin{array}{l}0.003 \text { *** } \\
(0.001)\end{array}$ \\
\hline REER & $\begin{array}{l}0.009 \\
(0.009)\end{array}$ & $\begin{array}{l}0.017 \\
(0.010)\end{array}$ & $\begin{array}{l}0.008 \\
(0.009)\end{array}$ & $\begin{array}{l}0.014 \\
(0.011)\end{array}$ & $\begin{array}{l}0.012 \\
(0.009)\end{array}$ & $\begin{array}{l}0.018 \\
(0.010)\end{array}$ \\
\hline TFP & $\begin{array}{l}-0.040 * * \\
(0.013)\end{array}$ & $\begin{array}{l}-0.278 * * \\
(0.080)\end{array}$ & $\begin{array}{l}-0.035^{* *} \\
(0.014)\end{array}$ & $\begin{array}{l}-0.231 * * \\
(0.083)\end{array}$ & $\begin{array}{l}-0.072 * * * \\
(0.010)\end{array}$ & $\begin{array}{l}-0.267 * * \\
(0.092)\end{array}$ \\
\hline $\mathrm{HC}$ & & $\begin{array}{l}-0.156^{* * * *} \\
(0.033)\end{array}$ & & $\begin{array}{l}-0.145^{* * *} \\
(0.034)\end{array}$ & & $\begin{array}{l}-0.161 \text { *** } \\
(0.040)\end{array}$ \\
\hline TFP*HC & & $\begin{array}{l}0.088 * * \\
(0.030)\end{array}$ & & $\begin{array}{l}0.069 * \\
(0.032)\end{array}$ & & $\begin{array}{l}0.073^{*} \\
(0.034)\end{array}$ \\
\hline $\log (\mathrm{GDP})$ & & $\begin{array}{l}0.194 * * * \\
(0.050)\end{array}$ & & $\begin{array}{l}0.168 * * * \\
(0.033)\end{array}$ & & $\begin{array}{l}0.133 * * \\
(0.049)\end{array}$ \\
\hline $\log \left(\mathrm{GDP}^{\wedge} 2\right)$ & & $\begin{array}{l}-0.023^{* * *} \\
(0.005)\end{array}$ & & $\begin{array}{l}-0.018 * * * \\
(0.003)\end{array}$ & & $\begin{array}{l}-0.013 * * \\
(0.004)\end{array}$ \\
\hline UNEMP & $\begin{array}{l}-0.003 * * * \\
(0.000)\end{array}$ & $\begin{array}{l}-0.002 * * \\
(0.001)\end{array}$ & $\begin{array}{l}-0.003^{* * * *} \\
(0.001)\end{array}$ & $\begin{array}{l}-0.002 * * \\
(0.001)\end{array}$ & $\begin{array}{l}-0.003 * * * \\
(0.000)\end{array}$ & $\begin{array}{l}-0.002 * * * \\
(0.001)\end{array}$ \\
\hline LABFORCE & $\begin{array}{l}-0.001 * * \\
(0.000)\end{array}$ & $\begin{array}{l}-0.001 * \\
(0.000)\end{array}$ & $\begin{array}{l}-0.002 * * * \\
(0.000)\end{array}$ & $\begin{array}{l}-0.001 * * \\
(0.000)\end{array}$ & $\begin{array}{l}-0.001 * * * \\
(0.000)\end{array}$ & $\begin{array}{l}-0.001 * \\
(0.000)\end{array}$ \\
\hline INT & $\begin{array}{l}0.000^{*} \\
(0.000)\end{array}$ & $\begin{array}{l}0.000 \\
(0.000)\end{array}$ & $\begin{array}{l}0.000 * \\
(0.000)\end{array}$ & $\begin{array}{l}0.000 \\
(0.000)\end{array}$ & $\begin{array}{l}0.001 * * * \\
(0.000)\end{array}$ & $\begin{array}{l}0.000^{*} \\
(0.000)\end{array}$ \\
\hline CRISIS & $\begin{array}{l}-0.009 * \\
(0.004)\end{array}$ & & $\begin{array}{l}-0.007 \\
(0.004)\end{array}$ & & $\begin{array}{l}-0.010 * \\
(0.005)\end{array}$ & \\
\hline Constant & $\begin{array}{l}0.665^{* * *} * \\
(0.018)\end{array}$ & $\begin{array}{l}0.628 * * * \\
(0.111)\end{array}$ & $\begin{array}{l}0.673 * * * \\
(0.017)\end{array}$ & $\begin{array}{l}0.645 * * * \\
(0.100)\end{array}$ & $\begin{array}{l}0.681 * * * \\
(0.019)\end{array}$ & $\begin{array}{l}0.746^{* * * *} \\
(0.093)\end{array}$ \\
\hline Country & Yes & Yes & Yes & Yes & Yes & Yes \\
\hline Year & Yes & Yes & Yes & Yes & Yes & Yes \\
\hline No. of Observations & 343 & 343 & 343 & 343 & 343 & 343 \\
\hline R-squared & 0.2929 & 0.3409 & 0.2904 & 0.3411 & 0.2549 & 0.3219 \\
\hline
\end{tabular}

Note: $* * * \mathrm{p}<0.01,{ }^{*} * \mathrm{p}<0.05,{ }^{*} \mathrm{p}<0.1$ 


\section{Conclusion}

The common argument in the modern economic perspective depends on the fact that the factor shares have been converged more in recent years compared to the previous periods. It is actually based on the phenomena that the driving forces of globalization have provided more opportunities in terms of both higher living standards and choices for different kinds of materials. However, some stylized facts of economic mechanism inversely show that the distribution of income has been much favored one factor to the detriment of another. In particular, during the last two decades, the gap between productivity gains and the real wage increases have diverged in many countries from both the industrial periphery and emerging groups. Although there are many reasons behind this gap, the paper focused on the effects of an increase in financialization on the labor share of income to understand whether this is significant or not in an empirical framework. The major challenge to make this analysis comprises of two factors. First, the literature on this relationship is very missing and limited. Therefore, the compare and contrast mechanisms among different empirical outcomes are restricted for making further analyses to promote certain findings of the relationship between financialization and the income shares. Second, the selection of financialization data is not straightforward due to the presence of alternative views about what is financialization itself and how can be measured for different economic structures.

This study proposed a context to understand the multidimensional relations among various indicators related to an ever-increasing financial sector and thus analyzed the role of financialization proxied by stock markets indicators on income distribution in 52 countries, including both developed and developing economies based on Kaleckian distribution model. While the empirical investigation used numerous measures to account for the hypothesized link between financialization and the decline in the labor share of national income, these were actually integrated to each other. For instance, the stock market development may be affected by the changes in globalization phenomena, technological progress, educational quality, and macroeconomic and structural indicators as well as the liberalization policies ongoing through finance and trade. Using a panel dataset for 21 years, the results suggest that the correlation between financialization and the decline in labor share of income is positive and highly significant in most of the regressions, which validates the Hypothesis 1. Moreover, the same link is also the case for the relationship between globalization measures and the labor share of income. In particular, liberalization of financial accounts and trade openness harms the labor's share over the 1992-2012 period. Therefore, Hypothesis 2 is also prevailing through the estimated model.

The main rationale depends on four potential reasons. First, one of the major reasons in decline of labor's share by way of financialization are based on the erosion of bargaining positions of workers over the capitalists, which is intensified by a higher level of flexibility in labor markets and raising short-term relations in business life, coupled with the implementation of more liberal policies in finance and trade, and an increase in globalized relations both in economic, social and political dimensions. Second, higher levels of stock market development were led to a squeeze in wages, resulting in a high degree of mark-up and thereby incomplete markets, and causing profits to increase on average. Third, the higher degree of openness in finance and trade, coupled with increasing impacts of globalized relations on distributional practices, contributed to the 
decline in the labor's share accruing in national income. Finally, the interaction terms of financialization indicators and financial liberalization measure added into the models to figure out whether financial liberalization conditions the effect of financialization on labor's share. The empirical outcomes indicated that promoting more open financial accounts without making stock markets more developed negatively affects labor's income share.

Additionally, unlike the traditional Kuznets hypothesis, the estimations results showed that there is a U-curve relationship between GDP per capita and income distribution, which give support to the other estimation results. Some of the potential reasons for Ucurve relationship can be ranged as follows: (i) institutional discrimination; (ii) social class segregation; (iii) social disorder; (iv) unequal distribution of wealth; and (v) political challenges. Therefore, the estimation results also validate Hypothesis 3.

Though the empirical results implemented many different aspects of the role of financialization on distributional practices between workers and capitalists, the need for further research on the determinants of income shares of labor still makes sense in the era of financialization. In that vein, the alternative channels of financialization apart from the stock markets can be implemented that can affect the functional income distribution. In addition, the data structure can be allowed for long-term estimations in a larger time interval by extending the sample size, which in turn provides a comparison between more economies covering both high-, middle- and lower-income. Moreover, besides the financialization measures, the more facets of neoliberalism can be taken into account in the empirical framework to analyze an aggregate impact of such critical additional indicators (e.g. structural change, labor movements) on functional income distribution on a broader basis.

Disclosure statement: The author reported no potential conflict of interest.

\section{References}

ABEL, J. R., DEY, I. and GABE, T. M. (2012). Productivity and the Density of Human Capital, Journal of Regional Science, 52(4), 562-586. DOI: 10.1111/j.14679787.2011.00742.x

ACEMOGLU, D. (2003). Patterns of Skill Premia, The Review of Economic Studies, 70(2), 199-230. DOI: 10.1111/1467-937X.00242

ACEMOGLU, D. and AUTOR, D. (2011). Skills, Tasks and Technologies: Implications for Employment and Earnings, in D. Card and O. Ashenfelter (eds.), Handbook of Labor Economics, 1043-1171, Amsterdam: Elsevier.

AIZENMAN, J. (2018). A modern reincarnation of Mundell-Fleming's trilemma, Economic Modelling, in press, corrected proof.

ALCALA, F. and CICCONE, A. (2004). Trade and Productivity, The Quarterly Journal of Economics, 119(2), 613-646. DOI: 10.1162/0033553041382139

ANDERSON, E. (2005). Openness and inequality in developing countries: A review of theory and recent evidence, World Development, 33(7), 1045-1063. 
ANDERSON, A. S. and NIELSEN, F. (2002). Globalization and the Great U-Turn: Income Inequality Trends in 16 OECD Countries, American Journal of Sociology, 107(5), 1244-1299. DOI: 10.1016/j.worlddev.2005.04.003

AUTOR, D. H., KATZ, L. F., and KRUEGER, A. B. (1998). Computing Inequality: Have Computers Changed the Labor Market?, The Quarterly Journal of Economics, 113(4), 1169-1214.

BARAN, P. (1957). The Political Economy of Growth. London and New York: Monthly Review Press.

BASU, P. and GUARIGLIA, A. (2007). Foreign Direct Investment, inequality, and growth, Journal of Macroeconomics, 29(4), 824-839. DOI: 10.1016/j.jmacro.2006.02.004

BECK, N. and KATZ, J. N. (1995). What to do (and not to do) with Time-Series CrossSection Data, The American Political Science Review, 89(3), 634-647. DOI: $\underline{10.2307 / 2082979}$

BENTOLILA, S. and SAINT-PAUL, G. (2003). Explaining Movements in the Labor Share, The B.E. Journal of Macroeconomics, De Gruyter, 3(1), 1-33, October.

BERMAN, E., BOUND, J., and GRILICHES, Z. (1994). Changes in the Demand for Skilled Labor within U.S. Manufacturing: Evidence from the Annual Survey of Manufacturers, The Quarterly Journal of Economics, 109(2), 367-397. DOI: $10.2307 / 2118467$

BLAU, B. M. (2018). Income inequality, poverty, and the liquidity of stock markets, Journal of Development Economics, 130, 113-126. DOI: 10.1016/j.jdeveco.2017.10.006

BOYER, R. (2000). Is a Finance-led growth regime a viable alternative to Fordism? A preliminary analysis, Economy and Society, 29(1), 111-145. DOI: $\underline{10.1080 / 030851400360587}$

BUMANN, S. and LENSINK, R. (2016). Capital account liberalization and income inequality, Journal of International Money and Finance, 61, 143-162. DOI: 10.1016/j.jimonfin.2015.10.004

CHEN, X., LIN, S. and REED, W. R. (2006). Another Look at What to Do with TimeSeries Cross-Section Data, Working Paper No. 04/2006, Department of Economics, College of Business and Economics, Christchurch: New Zealand.

CHINN, M. D. and ITO, H. (2002). Capital Account Liberalization, Institutions and Financial Development: Cross Country Evidence, National Bureau of Economic Research, NBER Working Paper Series No: 8967, June.

CHOI, C. (2006). Does foreign direct investment affect domestic income inequality?, Applied Economics Letters, 13(12), 811-814. DOI: 10.1080/13504850500400637

CRESPI, G., CRISCUOLO, C. and HASKEL, J. (2008). Productivity, exporting, and the learning-by-exporting hypothesis: direct evidence from UK firms, Canadian Journal of Economics, 41(2), 619-637. DOI: 10.1111/j.1540-5982.2008.00479.x 
CROTTY, J. (2005). The Neoliberal Paradox: The Impact of Destructive Product Market Competition and 'Modern' Financial Markets on Nonfinancial Corporation Performance in the Neoliberal Era, In. G. EPSTEIN (ed.), Financialization and the World Economy, Cheltenham and Northampton: Edward Elgar, 77-110.

DAS, M. and MOHAPATRA, S. (2003). Income inequality: the aftermath of stock market liberalization in emerging markets, Journal of Empirical Finance, 10(1-2), 217 248. 10.1016/S0927-5398(02)00025-7

DAVIS, D. R. (1996). Trade Liberalization and Income Distribution, NBER Working Papers, No. 5693, National Bureau of Economic Research.

DE LOECKER, J. (2013). Detecting Learning by Exporting, American Economic Journal: Microeconomics, 5(3), 1-21.

DREHER, A. (2006). Does globalization affect growth? Evidence from a new index of globalization, Applied Economics, 38(10), 1091-1110. DOI: $\underline{10.1080 / 00036840500392078}$

DRISCOLL, J. C. and KRAAY, A. C. (1998). Consistent Covariance Matrix Estimation with Spatially Dependent Panel Data, Review of Economics and Statistics, 80(4), 549560. DOI: $\underline{10.1162 / 003465398557825}$

DUMENIL, G. and LÉVY, D. (2004). Capital Resurgent: Roots of the Neoliberal Revolution. Cambridge, Massachusetts and London: Harvard University Press.

DUMENIL, G. and LÉVY, D. (2011). The Crisis of Neoliberalism. Cambridge, Massachusetts and London: Harvard University Press.

DÜNHAUPT, P. (2013). The effect of financialization on labor's share of income, Institute for International Political Economy Berlin, Working Paper No. 17/2003.

DÜNHAUPT, P. (2017). Determinants of labour's income share in the era of financialisation, Cambridge Journal of Economics, 41, 283-306. DOI: 10.1093/cje/bew023

EICHENGREEN, B., GULLAPALLI, R. and PANIZZA, U. (2011). Capital account liberalization, financial development and industry growth: a synthetic view, Journal of International Money and Finance, 30(6), 1090-1106. DOI: 10.1016/j.jimonfin.2011.06.007

EPSTEIN, G. (2005). Introduction: Financialization and the World Economy, In G. EPSTEIN, (ed.), Financialization and the World Economy, Cheltenham, UK and Northampton, MA, USA: Edward Elgar, 3-16.

FAVILUKIS, J. (2013). Inequality, stock market participation, and the equity premium, Journal of Financial Economics, 107(3), 740-759. DOI: 10.1016/j.jfineco.2012.10.008

FEENSTRA, R. C. and HANSON, G. H. (1996). Globalization, Outsourcing, and Wage Inequality, The American Economic Review, 86(2), 240-245

FEENSTRA, R. C. and HANSON, G. H. (1997). Foreign direct investment and relative wages: Evidence from Mexico's maquiladoras, Journal of International Economics, 42(3-4), 371-393. DOI: 10.1016/S0022-1996(96)01475-4 
FEENSTRA, R. C., INKLAAR, R. and TIMMER, M. P. (2015). The Next Generation of the Penn World Table, American Economic Review, 105(10), 3150-3182. DOI: /10.1257/aer.20130954

FINE, B. (2010). Neoliberalism as financialisation, Alfredo Saad-Filho and Galip L. Yalman (eds.), Economic Transitions to Neoliberalism in Middle-income Countries: Policy dilemmas, economic crises, forms of resistance, London and New York: Routledge, 11-23.

FOSTER, J. B. (2006). Monopoly-Finance Capital, Monthly Review, 58(7), December.

FOSTER, J. B. (2010). The Financialization of Accumulation, Monthly Review, 62(5), October.

FOSTER, J. B. and MCCHESNEY, R. W. (2009). Monopoly-Finance Capital and the Paradox of Accumulation, Monthly Review, 61(5), October.

GLYN, A. (2006). Capitalism Unleashed: Finance Globalization and Welfare. Oxford and New York: Oxford University Press.

GOLDBERG, P. K. and PAVCNIK N. (2004). Trade, Inequality and Poverty: What Do We Know? Evidence from Recent Trade Liberalization Episodes in Developing Countries, Brookings Trade Forum, 223-269.

GOLDBERG, P. K. and PAVCNIK, N. (2007). Distributional Effects of Globalization in Developing Countries, Journal of Economic Literature, 45(1), 39-82. DOI: $\underline{10.1257 / \mathrm{jel} .45 .1 .39}$

GOLLIN, D. (2002). Getting Income Shares Right, Journal of Political Economy, 110(2), 458-474. DOI: $10.1086 / 338747$

GOPINATH, M. and CHEN, W. (2003). Foreign direct investment and wages: a crosscountry analysis, The Journal of International Trade \& Economic Development, 12(3), 285-309. DOI: $10.1080 / 0963819032000132067$

GUERRIERO, M. (2012). The Labour Share of Income around the World: Evidence from a Panel Dataset, Institute for Development Policy and Management (IDPM), Development Economics and Public Policy Working Paper Series No: 32.

HAAN, J., PLENINGER, R. and STURM, J. E. (2018). Does the impact of financial liberalization on income inequality depend on financial development? Some new evidence, Applied Economics Letters, 25(5), 313-316. DOI: $\underline{10.1080 / 13504851.2017 .1319554}$

HALABY, C. N. (2004). Panel Models in Sociological Research: Theory into Practice, Annual Review of Sociology, 30, 507-544. DOI: $\underline{10.1146 / \text { annurev.soc.30.012703.110629 }}$

HARRISON, A. (2005). Has Globalization Eroded Labor's Share? Some Cross-Country Evidence, Munich Personal RePEc Archive, MPRA Paper No: 39649, April.

HEIN, E. (2006). Interest, Debt and Capital Accumulation-A Kaleckian Approach, International Review of Applied Economics, 20(3), 337-352. DOI: $\underline{10.1080 / 02692170600736128}$ 
HEIN, E. (2007). Interest Rate, Debt, Distribution and Capital Accumulation in a PostKaleckian Model, Metroeconomica, 58(2), 310-339. DOI: 10.1111/j.1467999X.2007.00270.x

HEIN, E. (2008). Money, Distribution Conflict and Capital Accumulation. Contributions to Monetary Analysis. Basingstoke: Palgrave Macmillan.

HEIN, E. (2010a). A Keynesian perspective on 'financialisation , in P. ARESTIS, and M. SAWYER (eds.), 21st Century Keynesian Economics, Basingstoke: Palgrave Macmillan.

HEIN, E. (2010b). Shareholder Value Orientation, Distribution and Growth - Short- and Medium-Run Effects in a Kaleckian Model, Metroeconomica, 61(2), 302-332. DOI: 10.1111/j.1467-999X.2009.04072.X

HEIN, E. (2012). The Macroeconomics of Finance-Dominated Capitalism-and its Crisis. Cheltenham: Edward Elgar.

HEIN, E. (2015). Finance-dominated capitalism and re-distribution of income: a Kaleckian perspective, Cambridge Journal of Economics, 39, 907-934. DOI: $\underline{10.1093 / \mathrm{cje} / \mathrm{bet} 038}$

HEIN, E. and VAN TREECK, T. (2010a). Financialisation and Rising Shareholder Power in Kaleckian/Post-Kaleckian Models of Distribution and Growth, Review of Political Economy, 22(2), 205-233. DOI: 10.1080/09538251003665628

HEIN, E. and VAN TREECK, T. (2010b). Financialisation in Post-Keynesian Models of Distribution and Growth-A Systematic Review, in M. SETTERFIELD (ed.), Handbook of Alternative Theories of Economic Growth, Cheltenham: Edward Elgar.

HERZER, D. and NUNNENKAMP, P. (2013). Inward and outward FDI and income inequality: evidence from Europe, Review of World Economics, 149(2), 395-422. DOI: $\underline{10.1007 / \mathrm{s} 10290-013-0148-3}$

HILFERDING, R. [1981] (2006). Finance-Capital: A Study of the Latest Phase of Capitalist Development, 2006 New Edition, London and Boston: Routledge \& Kegan Paul.

ILO (2011). World of Work Report 2011: Making markets work for jobs. Geneva: ILO.

IM, K. S., PESARAN, M. H. and SHIN, Y. (2003). Testing for unit roots in heterogeneous panels, Journal of Econometrics, 115(1), 53-74. DOI: 10.1016/S03044076(03)00092-7

ITO, K. (2012). Sources of Learning-by-Exporting Effects: Does Exporting Promote Innovation, Economic Research for ASEAN and East Asia (ERIA), Working Papers DP2012.

JAYADEV, A. (2007). Capital account openness and the labour share of income, Cambridge Journal of Economics, 31(3), 423-443. DOI: 10.1093/cje/bel037

KALECKI, M. [1954] (2003). Theory of Economic Dynamics. London: George Allen and Unwin. 
KINDLEBERGER, C. P. and ALIBER, R. (2005). Manias, Panics and Crashes: A History of Financial Crises. Basingstoke: Palgrave Macmillan.

KMENTA, J. (1986). Elements of Econometrics. $2^{\text {nd }}$ ed. New York: Macmillan.

KRIPPNER, G. R. (2011). Capitalizing on Crisis: The Political Origins of the Rise of Finance. Cambridge, Massachusetts and London: Harvard University Press.

KRISTAL, T. (2010). Good Times, Bad Times: Postwar Labor's Share of National Income in Capitalist Democracies, American Sociological Review, 75(5), 729-763. DOI: $\underline{10.1177 / 0003122410382640}$

KRUEGER, A. B. (1999). Measuring Labor's Share, National Bureau of Economic Research, NBER Working Paper No: 7006, March.

KUZNETS, S. (1955). Economic Growth and Income Inequality, American Economic Review, 45(1), 1-28.

LAPAVITSAS, C. (2010). Financialisation and Capitalist Accumulation: Structural Accounts of the Crisis of 2007-9, Research on Money and Finance, Discussion Papers No: 16.

LAPAVITSAS, C. (2013). The financialization of capitalism: 'Profiting without producing', City, 17(6), 792-805. DOI: 10.1080/13604813.2013.853865

LAVOIE, M. (1993). A post-classical view of money, interest, growth and distribution, in G. Mongiovi and C. Ruhl (eds.), Macroeconomic Theory: Diversity and Convergence, Cambridge: Cambridge University Press.

LAVOIE, M. (2014). Post-Keynesian Economics: New Foundations. Cheltenham: Edward Elgar.

LAZONICK, W. and O'SULLIVAN, M. (2000). Maximizing shareholder value: a new ideology for corporate governance, Economy and Society, 29(1), 13-35. DOI: $\underline{10.1080 / 030851400360541}$

LEE, E. and VIVARELLI, M. (2004). Understanding Globalization, Employment and Poverty Reduction. New York: Palgrave Macmillan.

LEVIN, A., LIN, C. F. and CHU, C. S. J. (2002). Unit root tests in panel data: asymptotic and finite-sample properties, Journal of Econometrics, 108(1), 1-24. DOI: $\underline{10.1016 / \mathrm{S} 0304-4076(01) 00098-7}$

MARTIN, R. (2002). Financialization of Daily Life. Philadelphia: Temple University Press.

MESCHI, E. and VIVARELLI, M. (2009). Trade and Income Inequality in Developing Countries, World Development, 37(2), 287-302. DOI: 10.1016/j.worlddev.2008.06.002

MILBERG, W. and WINKLER, D. (2013). Outsourcing Economics: Global Value Chains in Capitalist Development. Cambridge: Cambridge University Press.

NORRIS, P. (2000). Global governance and cosmopolitan citizens, In J. S. NYE and J. D. DONAHUE (eds.), Governance in a Globalizing World, Washington DC: Brookings Institution Press, 155-177. 
Palley, T. I. (2007). Financialization: What It Is and Why It Matters, The Levy Economics Institute Working Paper, No. 525, December.

PARKS, R. W. (1967). Efficient Estimation of a System of Regression Equations when Disturbances are Both Serially and Contemporaneously Correlated, Journal of the American Statistical Association, 62(318), 500-509. DOI: $\underline{10.1080 / 01621459.1967 .10482923}$

PIVA, M. and VIVARELLI, M. (2004). Technological change and employment: Some micro evidence from Italy, Applied Economics Letters, 11(6), 373-376. DOI: $\underline{10.1080 / 1350485042000228222}$

POLANYI, K. (2001). The Great Transformation: The Political and Economic Origins of Our Times. Boston: Beacon Press.

REINHARDT, D., RICCI, L. A. and TRESSEL, T. (2013). International capital flows and development: Financial openness matters, Journal of International Economics, 91(2), 235-251. DOI: 10.1016/j.jinteco.2013.07.006

ROBBINS, D. (2003). The impact of trade liberalization upon inequality in developing countries - A review of theory and evidence, ILO Working Paper, No.13, International Labour Organization, Geneva.

SAWHNEY, B. L. and DIPETRO, W. R. (2006). Stock Market Wealth and Income Inequality, The Journal of Business and Economic Studies, 12(1), 74-77.

SAWYER, M. (2013). What Is Financialization?, International Journal of Political Economy, 42(4), 5-18. DOI: 10.2753/IJP0891-1916420401

SCHWERDT, G. and TURUNEN, J. (2007). Changes in Human Capital: Implications for Productivity Growth in the Euro Area. Ifo Working Paper, No: 53, December.

SCHIFF, M. and WANG, Y. (2004). On the Quantity and Quality of Knowledge: The Impact of Openness and Foreign Research and Development on North-North and NorthSouth Technology Spillovers, Policy Research Working Paper Series 3190, The World Bank.

SÖDERBOM, M. and TEAL, F. (2004). Openness and Human Capital as Sources of Productivity Growth: An Empirical Investigation, Development and Comp Systems 0409031, University Library of Munich, Germany.

STOCKHAMMER, E. (2004). Financialisation and the slowdown of accumulation, Cambridge Journal of Economics, 28(5), 719-741. DOI: 10.1093/cje/beh032

STOCKHAMMER, E. (2009). Determinants of functional income distribution in OECD countries, Macroeconomic Policy Institute Studies, 5/2009, September.

STOCKHAMMER, E. (2010). Financialization and the Global Economy, PERI UMASS Working Paper, No. 240, University of Massachusetts, Amherst.

THOENIG, M. and Verdier, T. (2003). A Theory of Defensive Skill-Biased Innovation and Globalization, American Economic Review, 93(3), 709-728.

TSAI, P. L. (1995). Foreign direct investment and income inequality: Further evidence, World Development, 23(3), 469-483. DOI: 10.1016/0305-750X(95)00136-Z 
VERHOOGEN, E. A. (2008). Trade, Quality Upgrading, and Wage Inequality in the Mexican Manufacturing Sector, The Quarterly Journal of Economics, 123(2), 489-530. DOI: $10.1162 /$ qjec.2008.123.2.489

WILLIAMS, K. (2000). From shareholder value to present-day capitalism, Economy and Society, 29(1), 1-12. DOI: 10.1080/030851400360532

WOOD, A. (1994). North-South Trade, Employment and Inequality: Changing Fortunes in a Skill-Driven World. Oxford: Clarendon Press.

WOOD, A. (1997). Openness and Wage Inequality in Developing Countries: The Latin American Challenge to East Asian Conventional Wisdom, The World Bank Economic Review, 11(1), 33-57.

WU, J. Y. and HSU, C. C. (2012). Foreign direct investment and income inequality: Does the relationship vary with absorptive capacity?, Economic Modelling, 29(6), 21832189. DOI: $10.1016 /$ j.econmod.2012.06.013

ZHU, S. C. and TREFLER, D. (2005). Trade and inequality in developing countries: a general equilibrium analysis, Journal of International Economics, 65(1), 21-48. DOI: $\underline{10.1016 / j . j i n t e c 0.2003 .11 .005}$ 


\section{Appendix}

Table A1. Variables, definitions and sources

\begin{tabular}{|c|c|c|}
\hline Variable & Definition & Source \\
\hline $\begin{array}{l}\text { Labor share of } \\
\text { income }\end{array}$ & Compensation of employees/employees, persons & $\begin{array}{l}\text { Penn World } \\
\text { Tables } 9.0\end{array}$ \\
\hline $\begin{array}{l}\text { Stock market } \\
\text { capitalization }\end{array}$ & $\begin{array}{l}\text { Total value of all listed shares in a stock market as a } \\
\text { percentage of GDP }\end{array}$ & $\begin{array}{l}\text { Global Financial } \\
\text { Development } \\
\text { Database }\end{array}$ \\
\hline $\begin{array}{l}\text { Stock market } \\
\text { total value traded }\end{array}$ & $\begin{array}{l}\text { Total value of all traded shares in a stock market ex- } \\
\text { change as a percentage of GDP }\end{array}$ & $\begin{array}{l}\text { Global Financial } \\
\text { Development } \\
\text { Database }\end{array}$ \\
\hline $\begin{array}{l}\text { Stock market } \\
\text { turnover ratio }\end{array}$ & $\begin{array}{l}\text { Total value of shares traded during the period divided } \\
\text { by the average market capitalization for the period }\end{array}$ & $\begin{array}{l}\text { Global Financial } \\
\text { Development } \\
\text { Database }\end{array}$ \\
\hline $\begin{array}{l}\text { Financial liberal- } \\
\text { ization }\end{array}$ & $\begin{array}{l}\text { Standardized principal component of the variables that } \\
\text { indicate the presence of multiple exchange rates, re- } \\
\text { strictions on current account transactions, on capital } \\
\text { account transactions, and the requirement of the surren- } \\
\text { der of export proceeds. }\end{array}$ & $\begin{array}{l}\text { The Trilemma } \\
\text { Indexes, Aizen- } \\
\text { man (2018) }\end{array}$ \\
\hline $\begin{array}{l}\text { Real trade open- } \\
\text { ness }\end{array}$ & {$[($ Export+Imports $) / G D P] *$ Price of GDP } & $\begin{array}{l}\text { WDI, Penn } \\
\text { World Tables 9.0, } \\
\text { Author's Calcula- } \\
\text { tion }\end{array}$ \\
\hline FDI, inwards & Foreign direct investment: inwards flows ( $\%$ of GDP) & UNCTAD \\
\hline FDI, outflows & Foreign direct investment: outwards flows (\% of GDP) & UNCTAD \\
\hline $\begin{array}{l}\text { Economic glob- } \\
\text { alization }\end{array}$ & $\begin{array}{l}\text { The index of economic globalization which covers both } \\
\text { trade globalization and financial globalization indicators }\end{array}$ & $\begin{array}{l}\text { The KOF Global- } \\
\text { isation Index } \\
\text { Database }\end{array}$ \\
\hline $\begin{array}{l}\text { Government } \\
\text { expenditure }\end{array}$ & $\begin{array}{l}\text { General government final consumption expenditure ( } \% \\
\text { of GDP) }\end{array}$ & $\begin{array}{l}\text { World Develop- } \\
\text { ment Indicators }\end{array}$ \\
\hline $\begin{array}{l}\text { Real effective } \\
\text { exchange rate }\end{array}$ & Real effective exchange rate (CPI-based) & Bruegel Database \\
\hline $\begin{array}{l}\text { Total factor } \\
\text { productivity }\end{array}$ & $\begin{array}{l}\text { Welfare-relevant total factor productivity at constant } \\
\text { national prices }(2011=1)\end{array}$ & $\begin{array}{l}\text { Penn World } \\
\text { Tables } 9.0\end{array}$ \\
\hline Human capital & $\begin{array}{l}\text { Human capital index, based on years of schooling and } \\
\text { returns to education }\end{array}$ & $\begin{array}{l}\text { Penn World } \\
\text { Tables } 9.0\end{array}$ \\
\hline GDP per capita & Logarithm of GDP per capita (current US\$) & $\begin{array}{l}\text { WDI, Author's } \\
\text { Calculation }\end{array}$ \\
\hline $\begin{array}{l}\text { Unemployment } \\
\text { rate }\end{array}$ & Unemployment rate (\% of total labor force) & $\begin{array}{l}\text { IMF World Eco- } \\
\text { nomic Outlook, }\end{array}$ \\
\hline $\begin{array}{l}\text { Labor force } \\
\text { participation rate }\end{array}$ & $\begin{array}{l}\text { Labor force participation rate, total ( } \% \text { of total popula- } \\
\text { tion ages } 15+) \text { (modeled ILO estimate) }\end{array}$ & $\begin{array}{l}\text { World Develop- } \\
\text { ment Indicators }\end{array}$ \\
\hline Real Interest rate & Real interest rate $(\%)$ & $\begin{array}{l}\text { Data-Planet } \\
\text { Statistical Da- } \\
\text { tasets }\end{array}$ \\
\hline Crisis & Crisis (Dummy) & $\begin{array}{l}\text { Author's Calcula- } \\
\text { tion }\end{array}$ \\
\hline
\end{tabular}




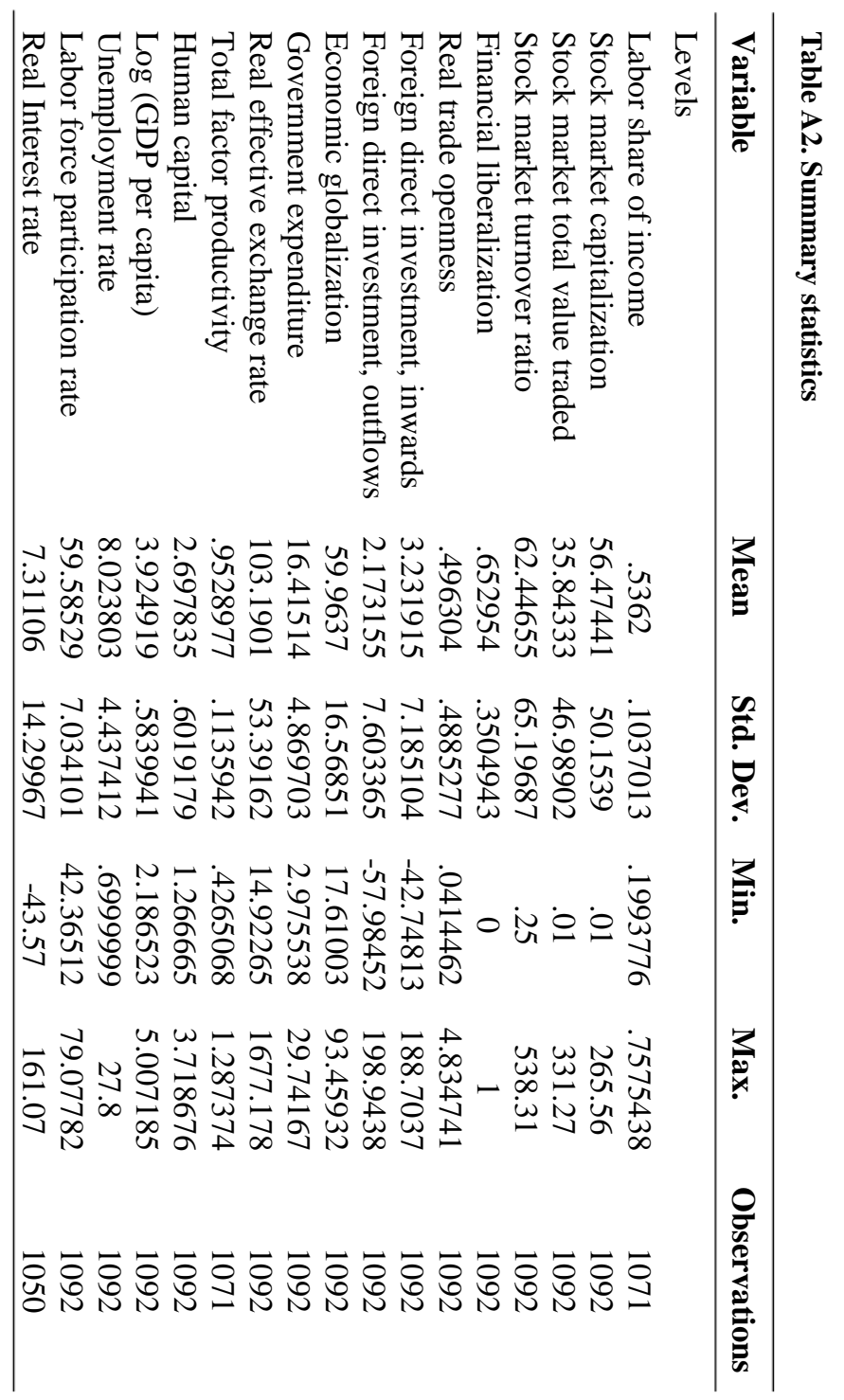


Table A3. List of selected countries

\begin{tabular}{ll}
\hline OECD Countries & Non-OECD Countries \\
\hline Australia & Argentina \\
Austria & Brazil \\
Belgium & China \\
Canada & Colombia \\
Chile & Costa Rica \\
Czech Republic & Cyprus \\
Denmark & Egypt \\
Finland & India \\
France & Indonesia \\
Germany & Iran \\
Greece & Jamaica \\
Hungary & Malaysia \\
Israel & Mauritius \\
Italy & Morocco \\
Japan & Nigeria \\
Korea (South) & Pakistan \\
Mexico & Peru \\
Netherlands & Philippines \\
Norway & Russia \\
Poland & Singapore \\
Portugal & Saudi Arabia \\
Spain & South Africa \\
Sweden & Thailand \\
Switzerland & Tunisia \\
Turkey & Venezuela \\
United Kingdom & \\
United States of America & \\
\hline & \\
\hline & \\
\hline
\end{tabular}

